OPEN ACCESS

Edited by:

Mohamed Boutjdir,

Veterans Affairs New York Harbor

Healthcare System, United States

Reviewed by:

Plinio Cirillo,

University of Naples Federico II, Italy

Salvatore De Rosa,

Università Degli Studi Magna Græcia

di Catanzaro, Italy

*Correspondence:

Bernhard Maisch

bermaisch@gmail.com

Specialty section:

This article was submitted to

Atherosclerosis and Vascular

Medicine,

a section of the journal

Frontiers in Cardiovascular Medicine

Received: 16 November 2018

Accepted: 27 March 2019

Published: 12 April 2019

Citation:

Maisch B (2019) Cardio-Immunology

of Myocarditis: Focus on Immune

Mechanisms and Treatment Options.

Front. Cardiovasc. Med. 6:48.

doi: $10.3389 /$ fcrm.2019.00048

\section{Cardio-Immunology of Myocarditis: Focus on Immune Mechanisms and Treatment Options}

\author{
Bernhard Maisch* \\ Faculty of Medicine, and Heart and Vessel Center, Philipps-University, Marburg, Germany
}

Myocarditis and inflammatory cardiomyopathy are syndromes, not aetiological disease entities. From animal models of cardiac inflammation we have detailed insight of the strain specific immune reactions based on the genetic background of the animal and the infectiosity of the virus. Innate and adaptive immunity also react in man. An aetiological diagnosis of a viral vs. a non-viral cause is possible by endomyocardial biopsy with histology, immunohistology and PCR for microbial agents. This review deals with the different etiologies of myocarditis and inflammatory cardiomyopathy on the basis of the genetic background and the predisposition for inflammation. It analyses the epidemiologic shift in cardiotropic viral agents in the last 30 years. Based on the understanding of the interaction between infection and the players of the innate and adaptive immune system it summarizes pathogenetic phases and clinical faces of myocarditis. It gives an up-to-date information on specific treatment options beyond symptomatic heart failure and antiarrhythmic therapy. Although inflammation can resolve spontaneously, specific treatment directed to the causative etiology is often required. For fulminant, acute, and chronic autoreactive myocarditis without viral persistence immunosuppressive treatment can be life-saving, for viral inflammatory cardiomyopathy ivlg treatment can resolve inflammation and often eradicate the virus.

Keywords: myocarditis, endomyocardial biopsy, immunohistology, PCR of cardiotropic viruses, immunopathogenesis, ivlg, immunosuppressive therapy

\section{INTRODUCTION}

More than a century ago, when coronary artery disease was neglectable, inflammation of the heart (=myocarditis) was thought to be the dominant cause of any cardiac disease (1). It has been known for decades that the heart is target of immunological effector organs, the T- and B-cells, their products such as circulating antibodies, mediators and cytokines (2). Nowadays, the heart is also considered an immunological organ reacting to damage and stress (3) and even with an antibody response to stress proteins (4). This occurs on the basis of a genetic background (5) and also epigenetic mechanisms (6), which led to the distinction between familial and non-familial cardiomyopathies in the latest classification of cardiomyopathies (7) and clarification of terms in the recent position statement of the working group on myocardial and pericardial diseases (8). Further insight in treatment options has been given in 2012 (9) and recently updated in 2018 (10).

The term cardiomyopathies is much younger than myocarditis and was first used by Hickie and Hall 1960 (11). The WHO/ISFC (World Health Organization/ International Society and Federation of Cardiology) Task Force defined it as "heart muscle diseases of unknown cause" 
(12). In 1996 the term cardiomyopathies was applied to all heart muscle diseases, which lead to functional impairment of the heart (13). Dilated cardiomyopathy (DCM) was one of 3 main clinical phenotypes (dilated, hypertrophic, restrictive cardiomyopathy). Remarkably, the 1996 task force included inflammatory heart muscle diseases (myocarditis, perimyocarditis), hypertensive, and ischemic cardiomyopathies and other forms of heart failure of known origin in the group of secondary cardiomyopathies. Inflammatory cardiomyopathy was then defined as inflamed myocardium assessed histologically as myocarditis in association with cardiac dysfunction. The pathohistological criteria at that time were the Dallas criteria (14), which distinguished active, recurrent, healing and borderline myocarditis. The etiology was assumed to be either Infectious, toxic or autoimmune. Non inflammatory viral cardiomyopathy was defined as viral persistence in a dilated heart without ongoing inflammation. Inflammatory cardiomyopathy was further specified in a World Heart Federation consensus meeting in 1999 by quantitative immunohistological criteria for inflammation ( $>14$ infiltrating cells $\left./ \mathrm{mm}^{2}\right)(15,16)$ and referred to it in the consensus document 2013 (8). These infiltrating cells in the myocardium could be Tand B lymphocytes, their activated forms and up to 4 monocytes or macrophages $/ \mathrm{mm}^{2}$. The underlying microbial agent had to be assessed or excluded by molecular biological methods, e.g., polymerase chain reaction (PCR) or in situ hybridization (17).

\section{LESSONS LEARNED FROM ANIMAL STUDIES}

Animal studies have contributed much to our understanding of the role of the immune system in cardiac homeostasis and disease (18):

1) In healthy mice hearts all major leukocyte classes including mononuclear phagocytes, neutrophils, $\mathrm{B}$ and $\mathrm{T}$ cells are present. They can be resident or from circulating blood. The normal mouse heart also contains resident cardiac dendritic cells and mast cells.

2) Between individual cardiomyocytes a network of resident macrophages exists, which are heterogeneous and ontogenetically diverse.

3) Leukocyte distribution is not uniform but the cells adhere to niches: Embryonically derived macrophages are adjacent to coronary vasculature, fetally derived monocytes are close to endocardial trabeculae, the aortic valve is rich in dendritic cells, the AV node contains a relatively high concentration of macrophages.

4) Immune cells and macrophages in particular also participate in organ development and steady-state physiology of tissue such as housekeeping tasks for maintaining cardiac function, cell and matrix turnover, and angiogenesis.

5) Macrophages interact with the conduction system. Depletion of macrophages in mice hearts may lead to conduction abnormalities (19).

6) The pericardial adipose tissue can readily supply leukocytes during myocardial injury. Mast cells accumulate preferably in white adipose tissue.
7) It has been shown that in injured hearts of mice and men resident and circulating leukocytes can be activated any form of injury such as in infarction (20) or after cardiac surgery (21).

8) Genetic studies indicated that susceptibility to Coxsackievirus (CV) B3 depended on the strain of mice used for infection. Virological studies revealed that different strains of CVB developed different magnitudes of cardiac organ involvement from very active forms of myocarditis to no inflammation at all. Also organ specificity for either heart and/or pancreas depended on the susceptibility of the mice. But also infectiosity of different CVB strains was important. More recently CVB3 strains were isolated with 5-terminal deletions in genomic RNAs from a patient with idiopathic dilated cardiomyopathy. These deletions lacked portions of the $5^{\prime}$ stem-loop I, which is a RNA secondary structure required for viral RNA replication. These findings suggest that even mutant viruses can be responsible for persistent infection. And in this changed structure they may also escape conventional PCR detection (22).

9) In the beginning of myocarditis viral infection of the heart is recognized by pattern recognition receptors (PRRs) such as toll like receptors (TLR) 2, 3, 4, 7, and 8. The downstream effects of each TLR activation may be different to each TLR, but all share a common a pro-inflammatory response. For instance after TLR2 stimulation by a damaged self-protein such as cardiac myosin monocytes produced pro-inflammatory cytokines such as IL-6, IL-8, and TNF$\alpha$. Cardiac myosin has often been used as antigen for immunization and initiation of experimental autoimmune myocarditis models. Viral murine myocarditis has focused on CVB3 infection. Signaling of the adaptor protein Myd88 downstream of TLR4 led to activation of NF- $\kappa B$, which decreased survival. In contrast signaling of adaptor protein TRIF up-regulates the antiviral IFN- $\beta$ response and improves survival.

10) In mice strains susceptible to infection with CVB3 myocardial disease occurs in 3 pathogenetic phases (infection, autoimmune reaction, dilated cardiomyopathy) with 3 symptomatic faces (malaise, inflammation, heart failure) $(23,24)$. In phase 1 CVB3 enters the myocardial cells via the coxsackie/adenoviral receptor (CAR) hereby initiating first the innate and later the adaptive immune responses. Mast cells as early responders produce proinflammatory cytokines (TNF, IL-1ß, IL-r). Neutrophils and monocytes produce additional mediators such as IL12. An increased production of interleukin-1b (IL-1b) and tumor necrosis factor-alpha during the early innate response to viral infection is a prerequisite for the induction of heartspecific autoimmune myocarditis. Its severity is determined by the number of $\mathrm{T}$ helper 1 (Th1) and Th2 cytokines. The Th1 pathway by interleukin-12 (IL-12) and gamma interferon (IFNgamma) is in principle proinflammatory and can lead to myocardial infiltration of the heart. It can also be down regulated by INFgamma production. The prototype Th2 cytokine is IL-4. It is frequent in severe forms of autoimmune myocarditis where eosinophils are prominent. 


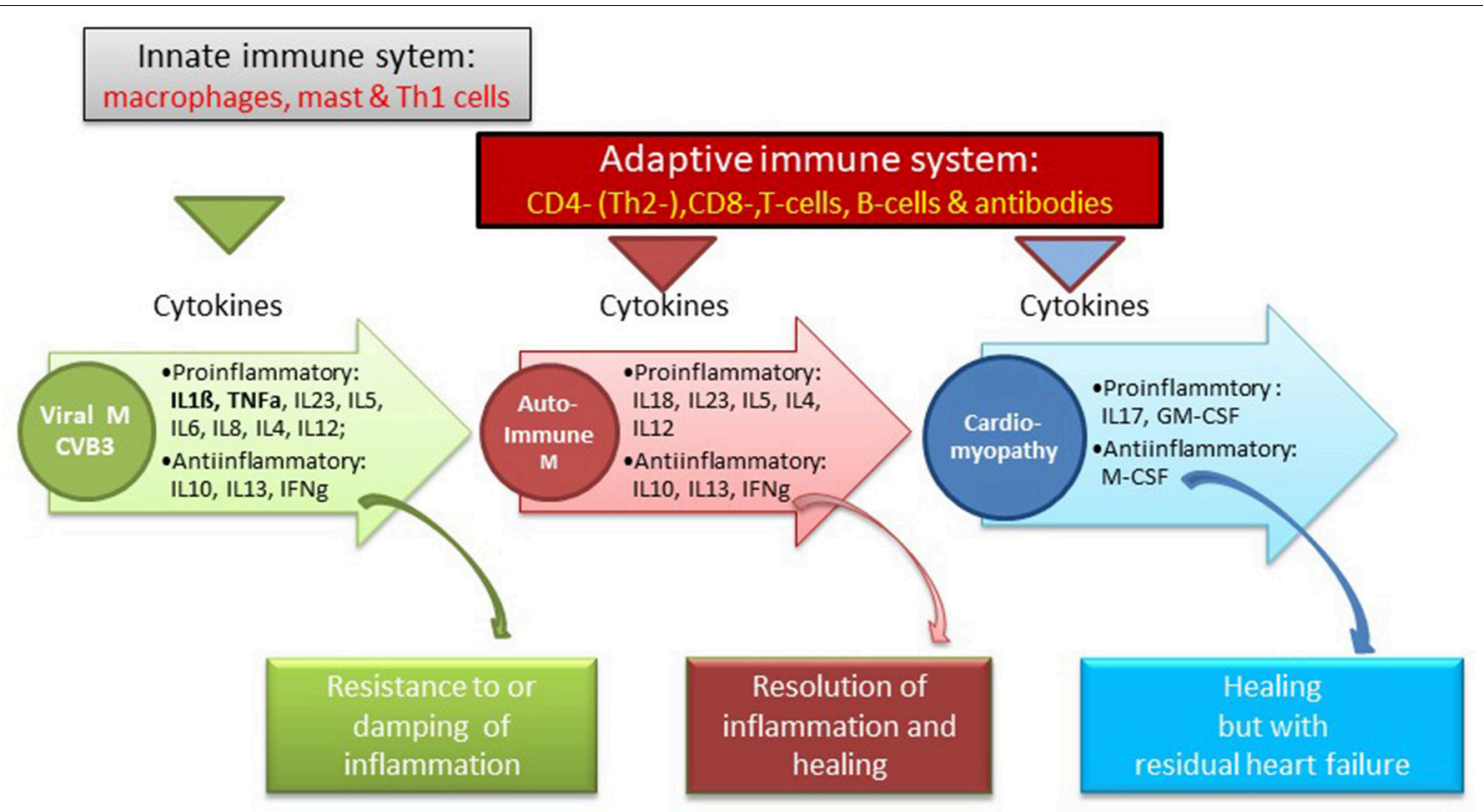

FIGURE 1 | Immune system and cytokine pattern in various susceptical and resistant mouse myocarditis models [Balbc, A/J mice, after CVB3 infection with a consecutive autoimmune reaction to cardiac myosi (25)].

Since it can go along with an IFNgamma increase, the disease is limited. IL-13, another Th2 cytokine, protects from infection, and reduces inflammation. Th17 cytokines also contribute to disease. The signature cytokine IL-17A is not essential for cardiac inflammation, but it is needed for the progression to heart failure (Figure 1) (25).

Myeloid differentiation primary response protein 88(MYD88) and IL-1 receptor-associated kinase 4(IRAK4) enhance myocardial inflammation by activating TNF receptorassociated factor 6(TRAF6) and nuclear factor-kappa b (NFKB). This decreases the production of antiviral type I interferons in the affected host. In phase 2 after presentation by dendritric cells the antigen-specific T-cells are the key players of cardiac damage. They may be counteracted by Treg cells. Inflammation may thus be ended or go on chronically as autoimmune reaction. $\mathrm{T}$ helper cells promote the development of cardiac dilatation by stimulating cardiac fibroblasts (phase 3). The autoimmune reactivity develops because coxsackievirus shares epitopes with cardiac myosin $(23,26)$, which as endogenous antigen contributes to this chronic inflammation.

Cardiac myosin as antigen has been used as a prototype protein in experimental autoimmune myocarditis (EAM), as well as many others antigens, e.g., Troponin I. They all can be prototypes of a B-cell driven myocarditis.

In these animal models phase 1, the infection phase, was followed by an antiviral and an autoimmune reaction (phase 2) (23, 26). This 2nd phase can be followed by lethal cardiac decompensation in a fibrotic heart with severe myocyte loss (phase 3) or by the resolution of the inflammation.
In man a similar triphasic pathogenetic process was assumed. The corresponding clinical correlates are malaise, inflammation and heart failure.

11) Our understanding of the pathogenetic processes following viral infection or myocyte destruction has been widened particularly by analyzing the steps leading to the activation of the innate immune system. The innate immune system is triggered by pathogen-associated molecular patterns (PAMP) and damage-associated molecular patterns (DAMP via Toll-like (TLR) and Nod-like receptors (NLR). These receptors are assembled in the inflammasome, which is a multiprotein intracellular complex located predominantly in macrophages. It activates proinflammatory cytokines such as interleukin-1b and IL-18 after detecting infective microbial agents or sterile stressors. Inflammasomes can also induce pyroptosis, a form of programmed cell death. They can induce the adaptive immune system consequently (27). A dysregulation of inflammasomes can be associated with autoimmune syndromes such as an autoreactive myocarditis (Figure 2).

\section{CLINICAL DIAGNOSIS IN HUMAN MYOCARDITIS}

According to the position statement of the European Society of Cardiology Working Group on Myocardial and Pericardial Diseases (8) the appropriate clinical work-up includes careful patient assessment for symptoms, auscultation, EKG for a new left bundle branch block (LBB) or severe recent rhythm disturbances at rest or exercise. Laboratory investigations 


\section{Pathogenetic mechanisms in myocardial inflammation}

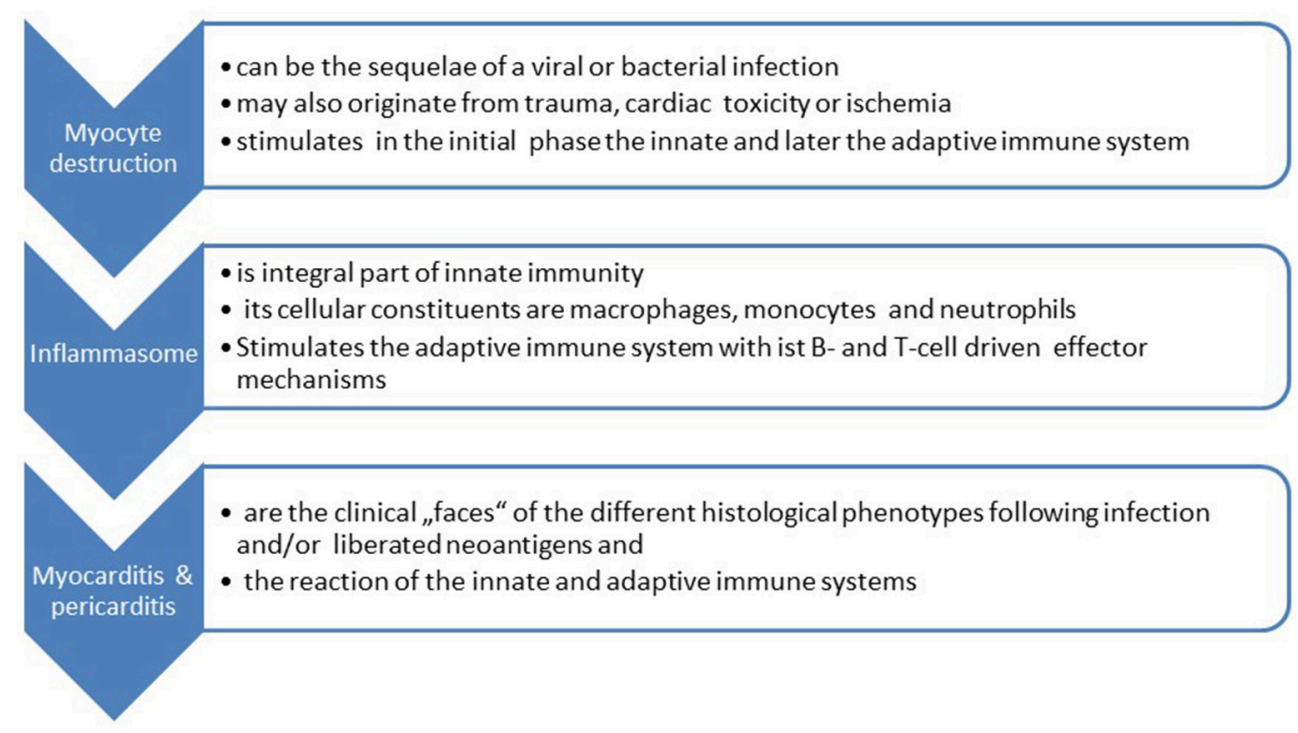

FIGURE 2 | Sequence of events in myocardial inflammation.

should include cardiac biomarkers such as nt-pro BNP for the assessment of heart failure, troponin I or T for myocyte necrosis and c-reactive protein (CRP) for inflammation. Among the non-invasive imaging techniques echocardiography can indicate cardiac inflammation, when in a symptomatic patient exhibits segmental or global wall motion abnormality and coronary artery disease or left bundle branch block (LBB) are not present. A small pericardial effusion in this context may also lead the way. Cardiac MRI is very helpful by establishing cardiac inflammation or postmyocarditic lesions in a follow-up investigation by early or late gadolinium enhancement (LGE). In principle the Lake Louise MRI protocol should be followed. But no noninvasive diagnostic method can substitute endomyocardial biopsy to reach a final aetiological diagnosis, when histology, immunhistology and PCR for microbial agents are evaluated together.

Clinical symptoms can be diverse, from to life-threating cardiogenic shock and lethal ventricular rhythm disturbances, acute or chronic heart failure or an acute chest wall syndrome. In some cases they might even allow a suspicion of the underlying pathogenetic process (Table 1).

Our understanding of the underlying aetiopathogenesis in man started some 35 years ago with the analysis of the antibody response to cardiac antigens in patients with suspected myocardial inflammation.

\section{AUTOANTIBODY-MEDIATED IMMUNE RESPONSE IN HUMAN MYOCARDITIS}

The humoral immune response was at that time assessed by the indirect immunoflourescence test or Elisa against
TABLE 1 | From symptoms to aetiological diagnoses.

\begin{tabular}{|c|c|c|}
\hline $\begin{array}{l}\text { Clinical } \\
\text { phenotype }\end{array}$ & Symptoms and features & Aetiological diagnoses \\
\hline $\begin{array}{l}\text { Acute } \\
\text { life-threating } \\
\text { heart failure, }\end{array}$ & $\begin{array}{l}\text { Shock, NYHA III-IV, elevated } \\
\text { Troponin I/T, elevated } \\
\text { Nt-proBNP }\end{array}$ & $\begin{array}{l}\text { Fulminant myocarditis, e.g., } \\
\text { giant cell or eosinophilia or } \\
\text { toxic myocarditis, borreliosis }\end{array}$ \\
\hline
\end{tabular}

severe rhythm

disturbance

Acute heart

failure(AHF)

Dyspnoe, edema, reduce

EF, but also diastolic AHF, variable EKG, intermittent Troponin I/T-and Nt-proBNP elevations

Chronic heart CHF symptoms, no CAD,

failure(CHF) EKG, with LSB, RSB,

AV-Block, variable

ST-/T-alterations, some

troponin $\mathrm{I} / \mathrm{T}$ and $\mathrm{Nt}$-proBNP elevations

Acute chest wall Angina like symptoms, but syndrome no CAD, variable

Parvovirus B19 or other ST-/T-alterations, in EKG, some Troponin $1 / T$ and

Viral or autoreactive myocarditis order inflammatory cardiomyopathy (DCMi)

Viral or autoreactive focal myocarditis or DCMi or borderline myocarditis

Nt-proBNP elevations cardiac proteins together with testing for antibodies against cardiotropic viruses. At that time we have focused on antibodies cross-reacting between enteroviral epitopes with cardiac myolemma and sarcolemma (28-31). We also examined the prevalence and possible pathogenicity against laminin (32), fibrils, intermediate filaments (33), and against mitochondria 


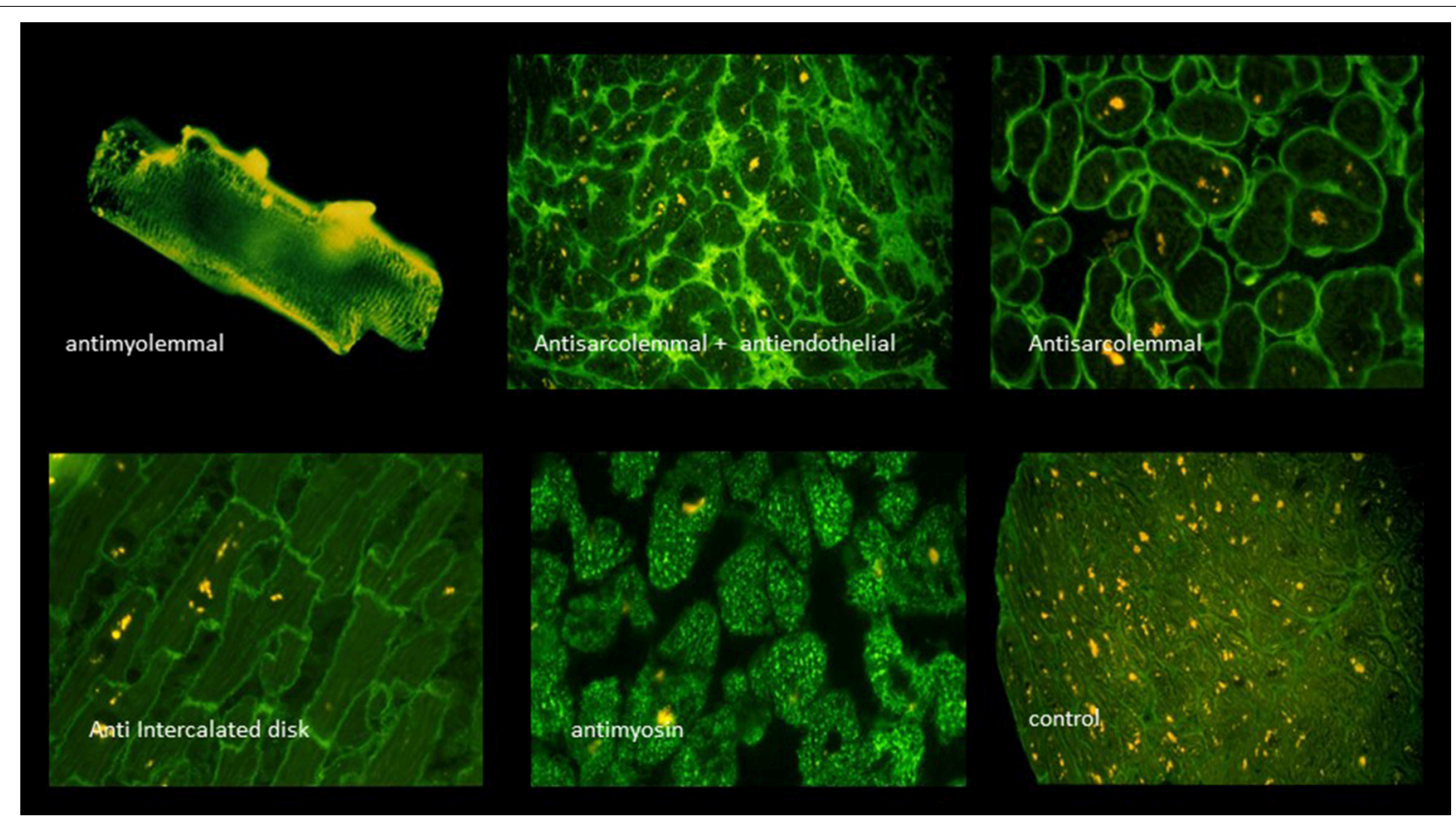

FIGURE 3 | A selection of circulating anticardiac antibodies [from Maisch and Pankuweit (9) with permission from Springer-Nature].
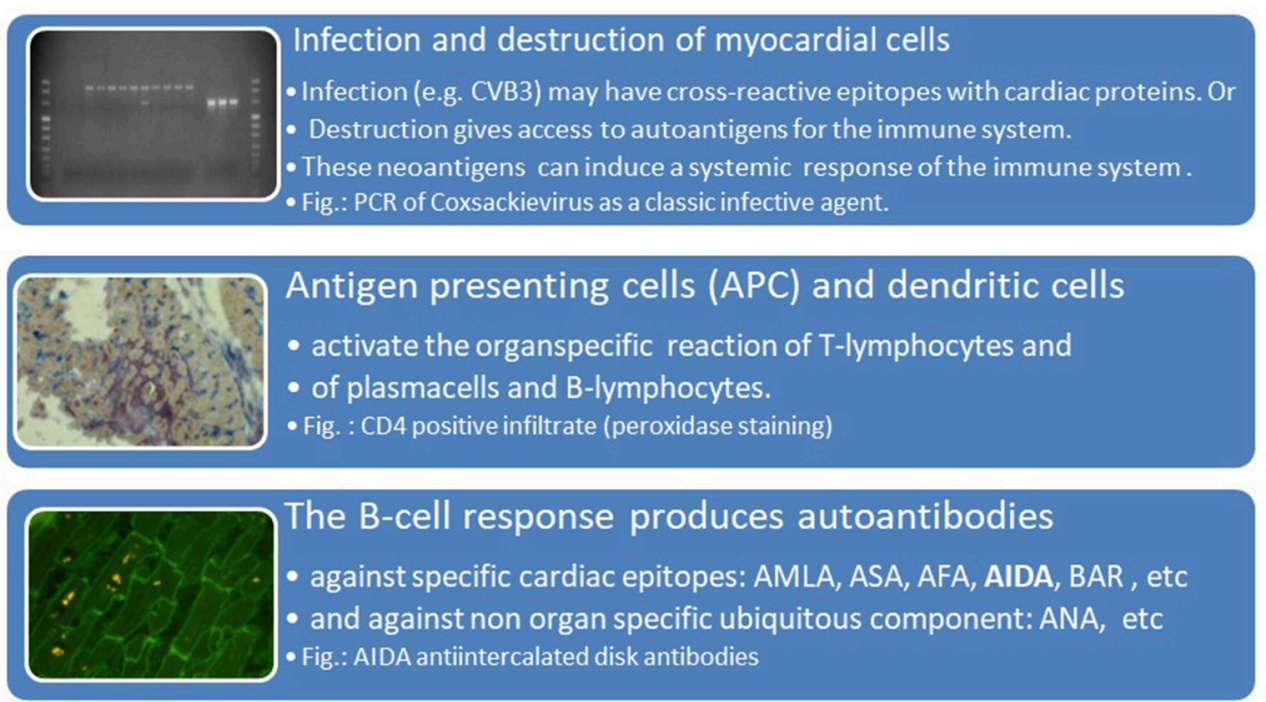

FIGURE 4 | Viral infection, antigen presentation, response by the adaptive immune system [inserted images from Maisch and Pankuweit (9) with permission from Springer-Nature]. AMLA, antimyolemmal antibodies(ab); ASA, antisarcolemmal ab; AFA, antifibrillary ab; AIDA, antiintercalated disk ab(fig.); BAR, betarecepator ab; ANA, antinuclear $a b$.

$(34,35)$. Antibodies directed against myofibrillar proteins $(36)$, troponins were in the focus of other investigators (37). Of particular interest was also the antibody response to the betareceptor in the sera of patients with myocarditis and dilated cardiomyopathy $(38,39)$ and the muscarinic acetylcholine receptor (40). Of note, also the cardiac conduction tissue was addressed by the humoral immune response to the sinus and atrioventricular nodes and Purkinje fibers $(41,42)$ (Figures 3, 4, Table 2).

\section{IMMUNE COMPLEXES}

Since anticardiac antibodies may find their corresponding targets in the circulating blood, in serous body fluids or the targeted tissue itself immune complexes may also play a role in the pathogenetic process (54).

The most important question still is, which of these antibodies were only diagnostic markers of former myocyte destruction similar to the antibodies after a vaccination or which antibodies 
TABLE 2 | Anticardiac antibodies [modified from Maisch and Pankuweit (9) with permission from Springer-Nature].

\begin{tabular}{|c|c|c|c|c|}
\hline Antigen & Antibody & $\begin{array}{l}\text { Cross- } \\
\text { reactivity }\end{array}$ & Pathomechanism & References \\
\hline Actin & Anti-actin & Unknown & Unknown & $(43)$ \\
\hline Acetylcholin-receptor & Anti-Ach & Unknown & Bradycardia & $(44)$ \\
\hline Aconitate hydratase & Anti-AH, & Unknown & Impaired metabolism & (31) \\
\hline Adenin nucleotide translocator & Anti-ANT & Enterovirus & Impaired metabolism & $(45)$ \\
\hline Beta1-receptor & Anti- $\beta 1$ & Enterovirus & Pos. chronotropic & $(38)$ \\
\hline Beta1-receptor & Anti- $\beta 1$ & & Neg. inotropic & $(46,47)$ \\
\hline Creatine kinase & Anti-CK & Unknown & Impaired metabolism & (31) \\
\hline Conduction system & $\begin{array}{l}\text { Anti-sinus node } \\
\text { Anti-AV node } \\
\text { Anti-Purkinje }\end{array}$ & Unknown & $\begin{array}{l}\text { Bradycardia } \\
\text { AV-Block } \\
\text { Conduction defect }\end{array}$ & $(41,42)$ \\
\hline Desmin & Anti-desmin & Unknown & Unknown & (33) \\
\hline Dihydrolipoamide dehydrogenase & Anti-DLD, & Unknown & Impaired metabolism & (31) \\
\hline $\begin{array}{l}\text { Extracted Nuclear Antigens } \\
\text { (ENA, SSA, SSB) }\end{array}$ & $\begin{array}{l}\text { ENA, ANCA } \\
\text { Anti-SSA } \\
\text { Anti-SSB }\end{array}$ & Unknown & $\begin{array}{l}\text { Neutrophil degranulation, } \\
\text { Congenital AV-Block }\end{array}$ & $(48)$ \\
\hline Hsp60, hsp70, Vimentin & $\begin{array}{l}\text { Anti-hsp60, } \\
\text { Anti-hsp70, } \\
\text { Anti-vimentin }\end{array}$ & Multiple & Unknown & (4) \\
\hline Laminin & Anti-laminin & Unknown & Unknown & $(32,49)$ \\
\hline Mitochondria /Microsomes & AMA & Multiple & $\begin{array}{l}\text { Inhibition of } \\
\text { sarcosin dehydrogenase }\end{array}$ & $(31,34,50)$ \\
\hline Myolemma & AMLA & Enterovirus & Lytic ab & $(2,28,29)$ \\
\hline Myosin & Anti-myosin & Enterovirus & Neg. inotropic & $(51,52)$ \\
\hline $\begin{array}{l}\text { Nicotinamideadenine-dinucleotide } \\
\text { dehydro-genase }\end{array}$ & Anti-NADD & Unknown & Impaired metabolism & (31) \\
\hline Nuclear Antigens & ANA & Unknown & $\begin{array}{l}\text { Immune complex } \\
\text { - mediated }\end{array}$ & (4) \\
\hline Pyruvate kinase & Anti-PK & Unknown & Impaired metabolism & (31) \\
\hline Troponin I (\& T) & Anti-Troponin I & Unknown & Negative inotropic & $(53)$ \\
\hline Ubiquinol-cyto-chrome-c-reductase & Anti-UCR & Unknown & Impaired metabolism & (31) \\
\hline Sarcolemma & ASA & Enterovirus & Lytic & $(3,24,26)$ \\
\hline
\end{tabular}

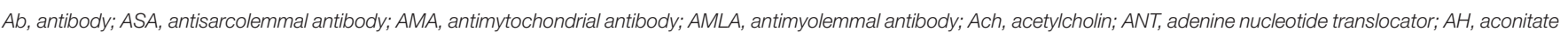

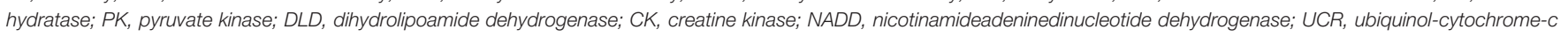
reductase; hsp, heat shock protein; ANA, antinuclear antigen; ANCA, anti-neutrophil cytoplasmic antigen; SR-Ca-ATPase, sarcoplasmatic reticulum calcium ATP-ase.

are pathogenetically truly harmful. Pathogenetic relevance was therefore attributed to those antibodies which were fixed to autologous cardiac tissue in the endomyocardial biopsy sample in vivo und proved cytolytic or protective in in vitro assays.

\section{IMPROVEMENTS IN HISTOLOGY, IMMUNOHISTOLOGY AND MOLECULAR BIOLOGY METHODS}

Endomyocardial biopsy (EMB) is the appropriate standard to diagnose myocarditis. It should be performed early in the course of the disease to optimize diagnostic accuracy and reduce the sampling error especially in focal myocarditis. Standard histology and immunohistology can be characteristic for certain types of inflammation (e.g., giant cell, eosinophilic myocarditis, sarcoidosis, lymphocytic). Immunohistology confirms the pathogenetic relevance of the autoantibodies, when they are fixed to the appropriate cardiac target protein. Polymerase chain reaction (PCR) identifies the underlying viral etiology or excludes it. This implies different treatment algorithms (13-17, 43, 55-59). Therefore, multiple specimens should be taken and immediately fixed in $10 \%$ buffered formalin. Additional samples should be snap frozen in liquid nitrogen for immunohistochemistry and stored at $-80^{\circ} \mathrm{C}$. And 1-2 samples should be stored in special tubes at room temperature for viral $\operatorname{PCR}(8,15,17,60)$. To increase the diagnostic sensitivity of immunohistochemistry, the use of a large panel of monoclonal and polyclonal antibodies including anti-CD3, anti-CD4, anti-CD8, anti-CD68, and anti HLA$\mathrm{DR}$ is mandatory for the identification and characterization of the inflammatory infiltrate $(8,15,17)$. Quantitative immunohistochemistry should be performed for infiltrating cells. Specific binding of these antibodies indicating an inflammatory reaction is demonstrated by peroxidase double staining procedure. 
TABLE 3 | Comparison of qualitative Dallas (14) and quantitative World Heart Federation (WHF) criteria (15, 16).

\begin{tabular}{|c|c|c|c|}
\hline Biopsy diagnosis & Dallas criteria & WHF criteria histology* & WHF criteria viral etiology \\
\hline $\begin{array}{l}1^{\text {st }} \text { EMB: } \\
\text { Active myocarditis }\end{array}$ & $\begin{array}{l}\text { Infiltrate (>5 per hpf or nests), } \\
\text { myocytolysis, } \\
\text { edema (only H\&E staining) }\end{array}$ & $\begin{array}{l}>50 / \mathrm{mm}^{2}=\text { fulminant } \mathrm{m} \\
>14 / \mathrm{mm}^{2}=\text { active } \mathrm{m}\end{array}$ & $\begin{array}{l}\text { (Quantitative) PCR on viruses } \\
\text { If positive: viral } \mathrm{m} \text {. or DCMi; If } \\
\text { negative: autoreactive } \mathrm{m} \text {. }\end{array}$ \\
\hline Borderline myocarditis & $\begin{array}{l}\text { Infiltrate (>5 per hpf or nests), (only } \\
\text { H\&E staining) }\end{array}$ & Not applicable & Not applicable \\
\hline No myocarditis & No infiltrate & $<14 / \mathrm{mm}^{2}$ & $\begin{array}{l}\text { If negative: DCM } \\
\text { If positive: viral DCM }\end{array}$ \\
\hline $\begin{array}{l}2^{\text {nd }} \text { EMB: } \\
\text { Ongoing myocarditis }\end{array}$ & $\begin{array}{l}\text { Infiltrate (> } 5 \text { per hpf or nests), } \\
\text { myocytolysis, edema } \\
\text { (only H\&E staining) }\end{array}$ & $>14 / \mathrm{mm}^{2}$ & $\begin{array}{l}\text { (Quantitative) PCR on viruses, } \\
\text { If positive: viral } \mathrm{m} \text {. or DCMi; If } \\
\text { negative: autoreactive } \mathrm{m} \text {. }\end{array}$ \\
\hline Healed/resolved myocarditis & No infiltrate, but focal fibrosis & $<14 / \mathrm{mm}^{2}$ & $\begin{array}{l}\text { If negative: DCM } \\
\text { If positive: viral DCM }\end{array}$ \\
\hline
\end{tabular}

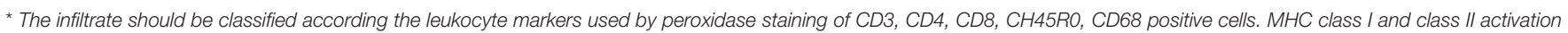
can be assessed.

DCMi, dilated cardiomyopathy with inflammation; EMB, endomyocardial biopsy; H\&E, hematoxilin and eosin staining; hpf, high power field; m, myocarditis.

Inflammation in endomyocardial biopsies is diagnosed by the WHF-criteria, which means a presence of $\geq 14$ leucocytes $/ \mathrm{mm}^{2}$ $(8,15)$ in European centers, whereas the qualitative Dallas criteria of active or borderline myocarditis in the first, and ongoing or resolving or resolved myocarditis in a subsequent biopsy are still applied in many American publications (Table 3).

An equally important diagnostic contribution of EMB comes from the molecular analysis with DNA-RNA extraction and RTPCR amplification of suspected viral genomes (15-17, 61), which is also part of the WHF criteria (Table 3). In order to exclude systemic infection, peripheral blood should be investigated in parallel with the biopsies $(15,17)$. Quantification of virus load and determination of virus replication may add diagnostic value (61). For detection of cardiotropic viruses total DNA and RNA should be extracted from the biopsy samples. Primer pairs specific for Coxsackievirus B (CVB), parvovirus B19 (PVB19), cytomegalovirus (CMV), adenovirus type 2, influenza virus A, human herpes virus 6 (HHV6) and Epstein-Barr virus (EBV) should be used to perform polymerase chain reaction (PCR) and in case of PVB19 quantitative real-time PCR to determine viral load.

\section{HISTOLOGICAL PHENOTYPES AND CLINICAL MANIFESTATIONS}

The association of the clinical phenotypes such as cardiogenic shock with fulminant myocarditis, acute heart failure with active lymphocytic or other forms of viral and non-viral myocarditis and chronic heart failure with borderline myocarditis can be derived from Table 1 and Figure 5. The biopsy findings in these patients fit into these histopathological categories. The inflammasome is a platform in cells of the innate immune system allowing transition from the innate to the adaptive anticardiac immune response directed against myocardial and pericardial targets $(11,46,62)$. The proinflammatory cascade in inflammasomes can be terminated intrinsicly, for example by Caspase-1 self-cleavage (63).

\section{EPIDEMIOLOGICAL INSIGHT BY HISTOLOGY AND PCR BASED ETIOLOGIES IN PATIENTS WITH SUSPECTED MYOCARDITIS}

The last WHO report on the epidemiology of inflammatory heart diseases, which explicitly listed viral causes of myocarditis dates back to the year 1981. It filed the following incidences of viral myocarditis per 1000: Coxsackie- B 36, Influenza- B 18, Influenza A- 12, Coxsackie A- 10, Cytomegalo- 9, Echo- 7, Adeno- 5 und Epstein Barr Virus 4,5. Meanwhile epidemiological data show a wide divergence in different parts of the world with new endemics or epidemics. To follow epidemiological trends one can assess the incidence of aetiological factors in changing frequencies as assessed by endomyocardial biopsies in tertial referral centers. Their data have limits by the sample size of all biopsied patients per year as the denominator. The region or sometimes the continent could be another selection bias. Registries can show longitudinal trends, however. Our registry of suspected myocarditis / inflammatory dilated cardiomyopathy was started 1987. The histological diagnosis of myocarditis was based on the Dallas criteria in the first years 10 years. Later on we used the quantitative WHF-criteria and refined the PCR for cardiotropic microbial agents as part of a common consensus. By a longitudinal comparison an epidemiological shift from entero- and adenoviruses to Parvovirus B19 becomes apparent (Figure 6A).

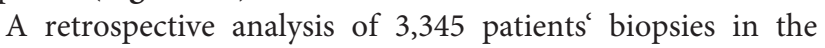
Marburg registry (60) revealed (Figure 6B):

- Only one third of the patients who underwent endomyocardial biopsy with the suspected diagnosis myocarditis or dilated cardiomyopathy showed inflammation in their biopsy.

- The greatest proportion of the patients was virus-negative, however. This applied to the patients with dilated cardiomyopathy with no inflammation. Such patients with an EF between 45 and 55\% (3rd column) made up $71.5 \%$, those with an $\mathrm{EF}<45 \%$ were virus-negative in 

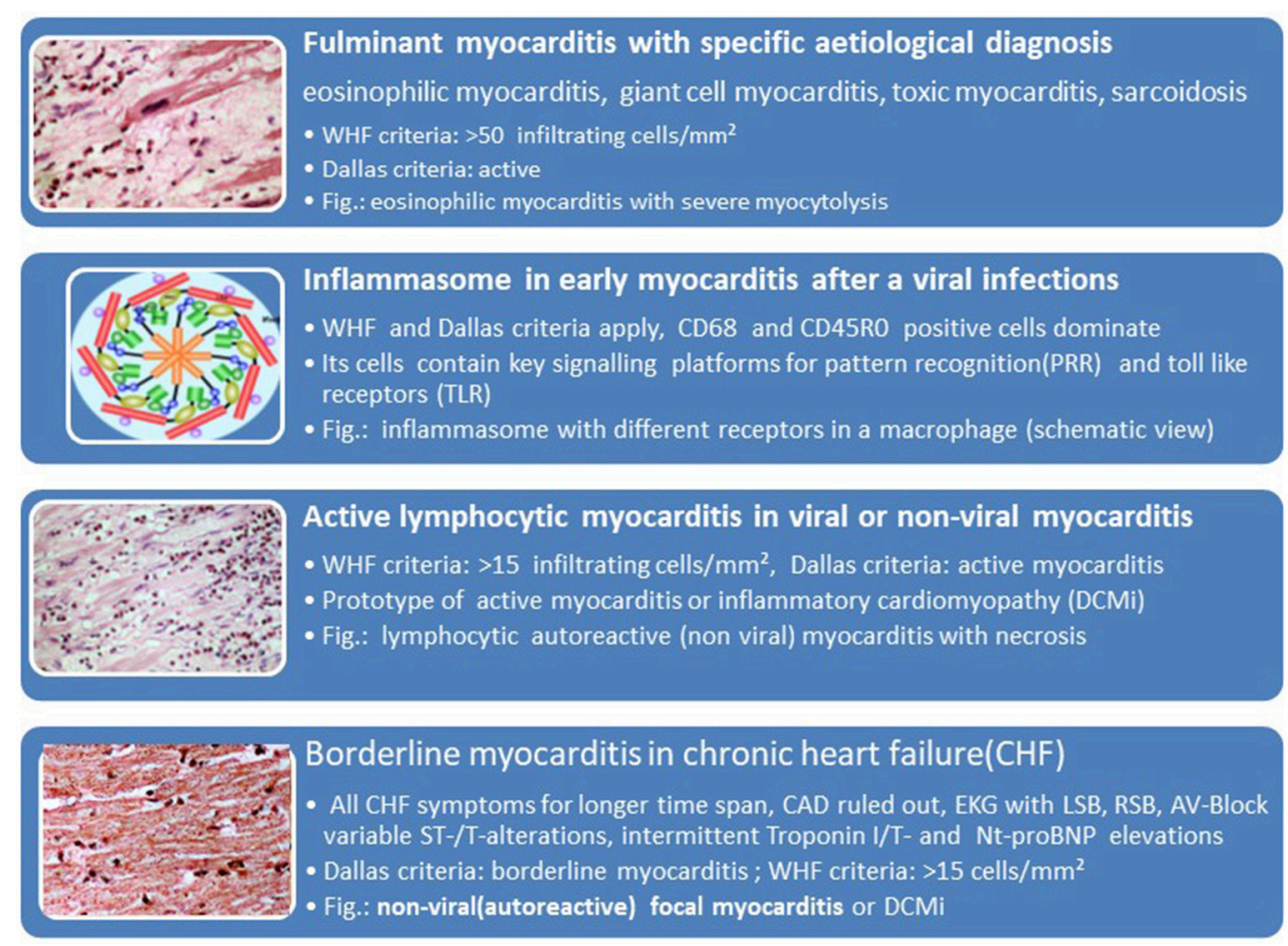

FIGURE 5 | Histological phenotypes and components of myocarditis and inflammatory cardiomyopathy can correlate with clinical manifestations (faces).

79.8\%. These groups are identical with heart failure of unknown origin.

- Parvovirus B 19 became by far the leading viral aetiological factor across all 4 groups of cardiomyopathies with or without inflammation. It ranged between $17.6 \%$ in non-inflammatory but viral cardiomyopathy (=viral heart disease) and $33.3 \%$ in inflammatory Parvovirus B19 positive cardiomyopathy with an $\mathrm{EF}<45 \%$.

\section{FUTURE SEROLOGIC DIAGNOSTIC MARKERS}

Distinct patterns of microRNAs are well described in coronary artery disease and myocardial infarction but not yet in inflammatory cardiomyopathies. De Rosa et al recently showed different gradients of microRNA expression in ischemic and non-ischemic forms of heart failure (64).

\section{Treatment}

Current recommendations and guidelines for the treatment of heart failure also apply to inflammatory cardiomyopathy. "Unloading the heart" is the principle of chronic heart failure of any cause. This has been successfully demonstrated in many heart failure trials on ACE-inhibition and angiotensin receptor blockade. Details and a comprehensive bibliography were summarized previously (9). Waagstein et al. demonstrated first a positive trend for betablockade in congestive cardiomyopathy (65).
Antiphlogistic treatment with non-steroidal antiinflammatory drugs (NSAIDs) such as ibuprofen or indomethacin or IL-antagonists such as anakinra should be reserved for patients with additional pericardial involvement. NSAIDs should be used only for short term application $(66,67)$, since in murine Coxsackie B3 myocarditis it was shown that NSAIDs can be detrimental (68). NSAIDs are cyclooxigenase inhibitors. Anakinra blocks the cytokine activity of IL-1. In peri (myo)carditis first line treatment with colchicine is now recommended not only in recurrent forms but also for the first attack of pericarditis (67). Figure 7 shows that colchicine is an inhibitor of the mitosis of tubulin in macrophages and neutrophiles. Its application inhibits primarily the innate immune system.

Antiarrhythmic treatment and device therapy also follows current heart failure guidelines [see Maisch and Pankuweit (9) for references].

\section{Stem Cell Transplantation}

Virtually no data on stem cell transplantation in myocarditis with heart failure and only scarce uncontrolled data in patients with dilated cardiomyopathy are available (9).

\section{SPECIFIC TREATMENT ALGORITHMS}

Figure 8 reflects diagnostic and therapeutic algorithms in different forms of myocarditis. They are also the basis of the double-blind randomized European Study on Epidemiology and Treatment of Inflammatory Myocardial Disease (ESETCID) (70). 


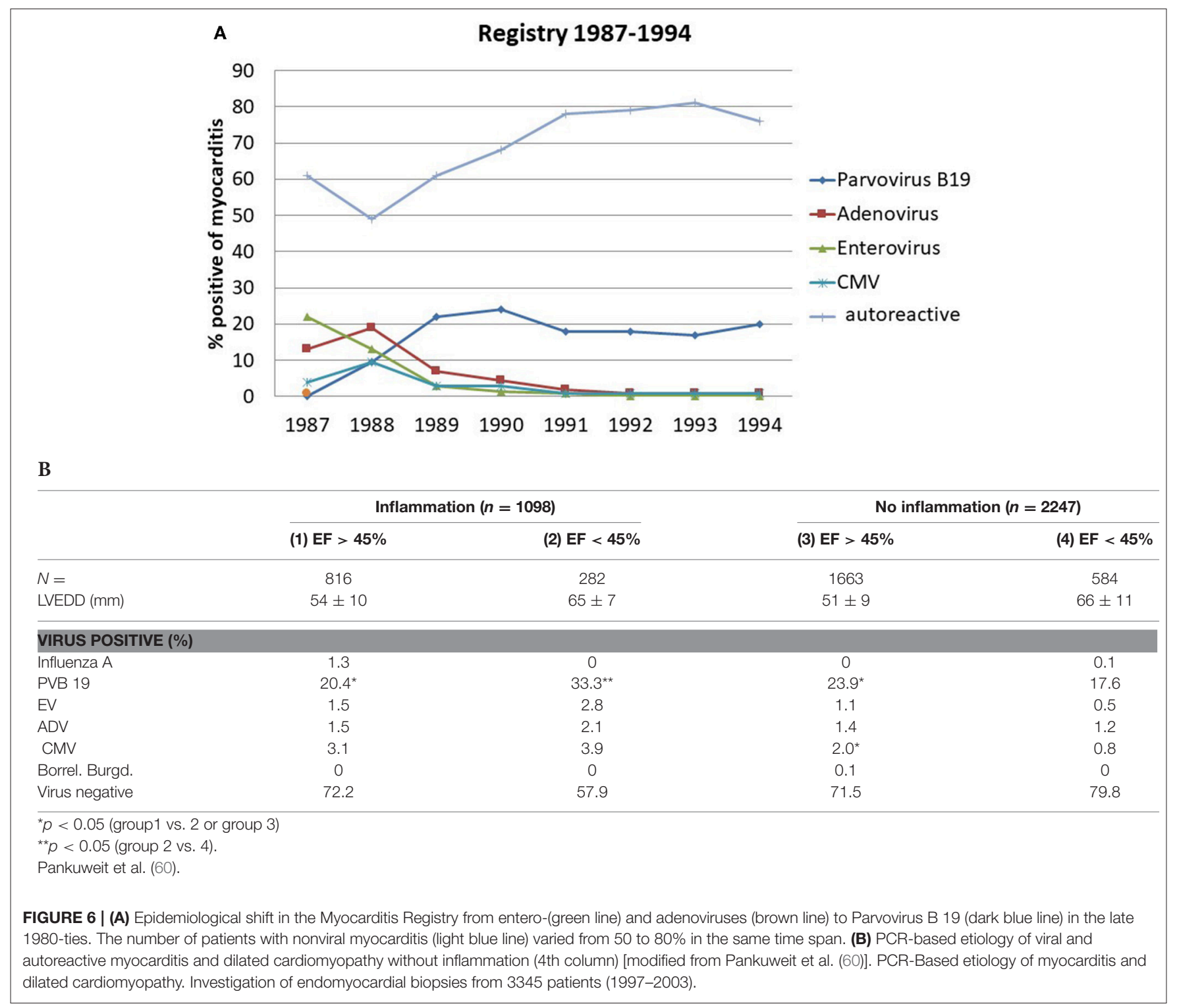

\section{Immunosuppressive Treatment Idiopathic Giant Cell Myocarditis}

Giant cells in addition to a lymphocytic infiltrate are the histological hall-mark of this very rare, fulminant and often lethal disease. If suspected, it is a clear biopsy indication. Its prevalence in Marburg registry $1989-2012$ is 3 in 10,000 biopsied patients. The etiology is considered autoimmune based on a genetic predisposition. It resembles experimental giant cell myocarditis in Lewis rats after immunization with myosin (71). When compared to an isolated cardiac sarcoid the histological differential diagnosis is sometimes difficult (72). If untreated the natural course is lethal. The giant cell myocarditis treatment trial proposed treatment with $5 \mathrm{mg}$ monoclonal anti CD3-antibodies given i.v. for 10 days. Cyclosporin should be started with $25 \mathrm{mg}$ bid and increased daily by $25 \mathrm{mg}$ to achieve a target serum level of $200 \mathrm{ng} / \mathrm{ml}$. This serum level should be kept for 1 year. Methylprednisolone should be started with $10 \mathrm{mg} / \mathrm{kg}$ i.v. for 3 days and then be tapered after 3 weeks to a final dose of $5 \mathrm{mg}$ for the rest of the year $(73,74)$. The study was stopped for lack of patients (Table 4).

\section{Cardiac Sarcoidosis}

In cardiac sarcoidosis the giant cells are only found in the non caseous granuloma $(94,95)$. In our registry it is 6-times more frequent with 19 in 10,000 biopsied patients than giant cell myocarditis. Granuloma are often located in the midmyocardial layer, which is not accessible to endomyocardial biopsy. So the diagnosis of cardiac sarcoidosis can be suspected in patients with systemic sarcoidosis and a biopsy just showing myocarditis. Early cardiac symptoms can be AV-block or severe ventricular arrhythmias leading to sudden death or severe heart failure. The etiology of sarcoidosis remains obscure, although recently a variant in the $b t n l 2$ gene and the $b t n l 2$ risk allele were described as risk factors $(9,96,97)$. The treatment is either corticoid treatment 


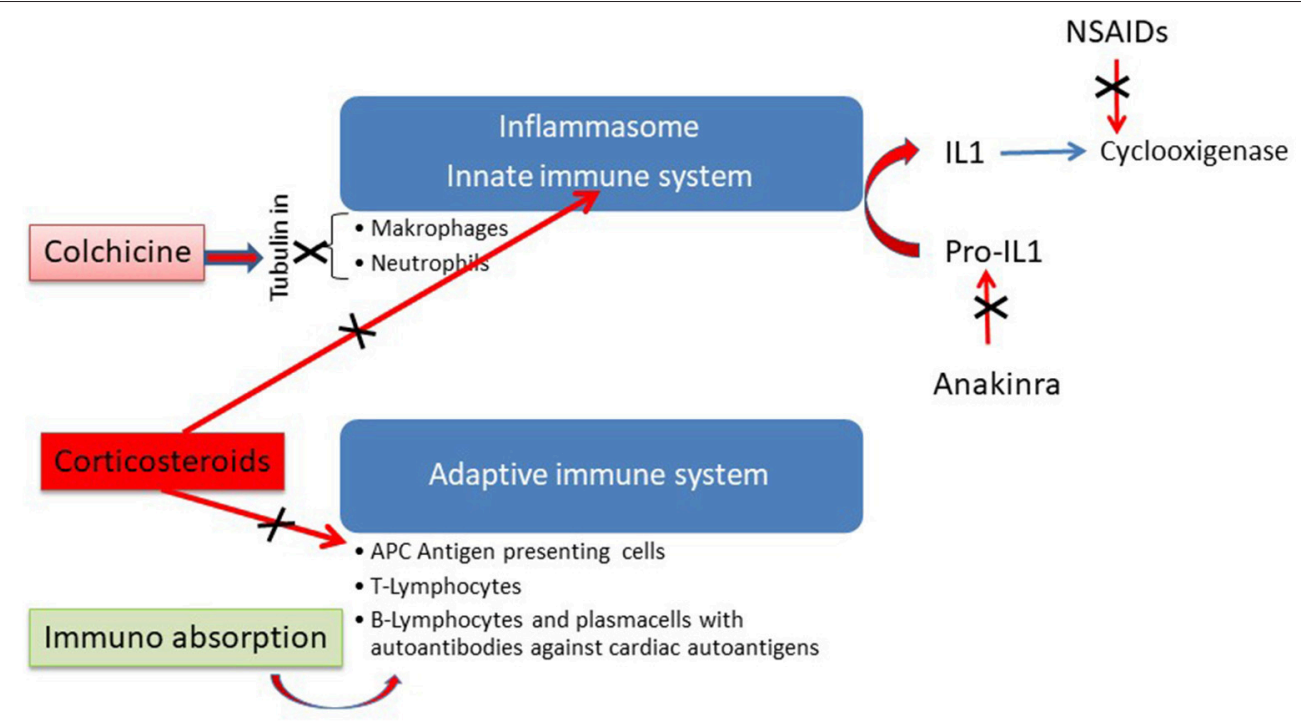

FIGURE 7 | Antininflammatory action of different modes of therapy in perimyocarditis [modified from Maisch (69) with permission from Springer-Nature].

\section{Specific treatment}

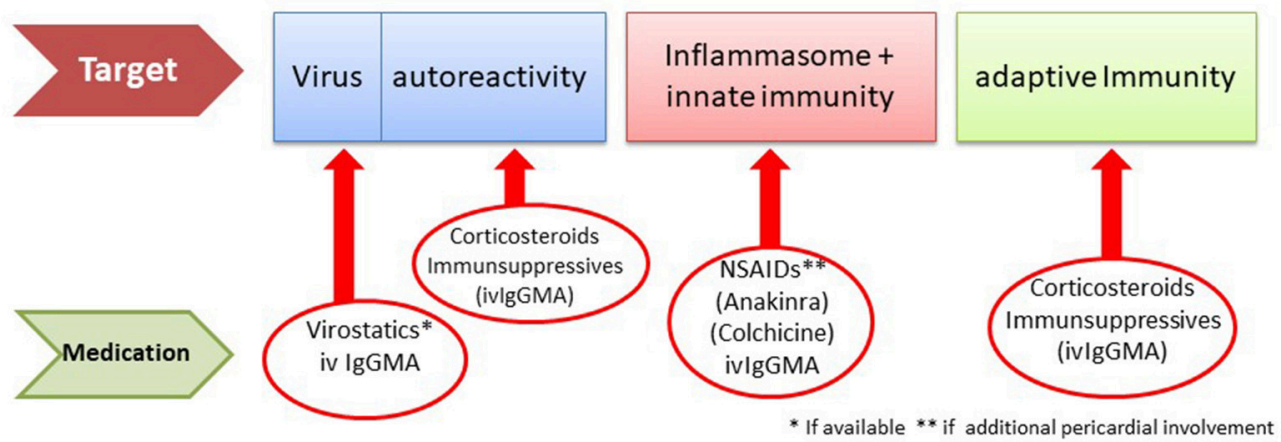

FIGURE 8 | Etiology driven treatment in myocarditis and inflammatory cardiomyopathy [modified from Maisch (69) with permission from Springer-Nature].

alone or in combination with other immunosuppressive drugs e.g., azathioprine or cyclosporine (98).

\section{Eosinophilic Heart Disease}

Eosinophilic heart disease (EHD) and endstage endomyocardial fibrosis are rare diseases. The Marburg Registry has collected 10 cases over 23 years. Its common pathogenetic denominator is the excessive production of cytotoxic eosinophils, which could damage the heart in different ways $(9,99,100)$ :

a) In the course of an allergic reaction,

b) As an autoimmune disease,

c) As malignant eosinophilic leukemia,

d) Following a parasitic or protozoal infection (tropical form),

e) As Churg-Strauss-syndrome or 
TABLE 4 | Trials for immunosuppressive treatment in myocarditis [modified from Maisch and Pankuweit (9) with permission from Springer-Nature].

\begin{tabular}{|c|c|c|c|c|c|c|c|c|}
\hline References & Treatment & $\begin{array}{l}\text { No pts/ } \\
\text { Controls }\end{array}$ & $\begin{array}{l}\text { Treated pts } \\
\text { improved }\end{array}$ & $\begin{array}{l}\text { Treated pts } \\
\text { Unch/deter. }\end{array}$ & $\begin{array}{l}\text { Controls } \\
\text { improved }\end{array}$ & $\begin{array}{l}\text { Controls } \\
\text { unch/deter. }\end{array}$ & Endpoint/Comments & \\
\hline \multicolumn{9}{|c|}{ A. OBSERVATIONAL STUDIES AND SMALL TRIALS WITH IMMUNOSUPPRESSION } \\
\hline Fenoglio et al. (75) & $P, A \& P$ & $18 / 4$ & $7(39 \%)$ & $11(61 \%)$ & $2(50 \%)$ & $2(50 \%)$ & \multicolumn{2}{|l|}{ EF/observational, no PCR } \\
\hline Hosenpud et al. (76) & $A \& P$ & $6 / 0$ & $0(0 \%)$ & $6(100 \%)$ & & & \multicolumn{2}{|l|}{$\begin{array}{l}\text { EF/No co, no PCR, no co } \\
\text { biopsy }\end{array}$} \\
\hline Anderson et al. (77) & $A \& P$ & $10 / 7$ & $3(30 \%)$ & $7(70 \%)$ & $2(28,5 \%)$ & $5(71,5 \%)$ & \multicolumn{2}{|l|}{$\begin{array}{l}\text { Prospective, open label, } \\
\text { randomized }\end{array}$} \\
\hline Marboe and Fenoglio (78) & $P, A \& P$ & $16 / 18$ & $9(56 \%)$ & $7(44 \%)$ & 7 (39\%) & $11(61 \%)$ & \multicolumn{2}{|l|}{$P, A \& P$ mixed } \\
\hline Latham et al., (79) & $P$ & $26 / 26$ & Majority & Minority & nd & nd & \multicolumn{2}{|l|}{ EF/No viral PCR, no biopsy } \\
\hline Maisch et al. (80) & $A \& P$ & $\begin{array}{l}21 / 21 \text { all virus } \\
\text { negative }\end{array}$ & $10(47 \%)$ & $11(53 \%)$ & $3(14 \%)$ & $18(86 \%)$ & \multicolumn{2}{|l|}{ EF (6 mo)/RCT pilot } \\
\hline Kühl et al. (81) & $\mathrm{P}$ & $31 / 0$ & $20(54 \%)$ & $11(46 \%)$ & nd & nd & \multicolumn{2}{|l|}{ EF; observational/ No co EMB } \\
\hline Camargo et al. (82) & $\mathrm{P}$ & $68 / 0$ & Majority & Minority & nd & nd & \multicolumn{2}{|l|}{ EF/observational, No viral PCR } \\
\hline Liu Dezue et al. (83) & $\mathrm{D}$ & $128 / 0$ & $\begin{array}{l}\text { Favorable, } \\
\text { but no data }\end{array}$ & nd & nd & nd & \multicolumn{2}{|l|}{ Observational/No EMB, CM } \\
\hline Sun (84) & $\mathrm{D}$ & $32 / 0$ & Majority & Minority & nd & nd & \multicolumn{2}{|l|}{$\begin{array}{l}\text { EF/observational, EKG only, no } \\
\text { PCR, CM }\end{array}$} \\
\hline Wu and Chen (85) & $D \& P$ & $31 / 0$ & Majority & Minority & nd & nd & \multicolumn{2}{|l|}{ Observational/ No EMB, CM, } \\
\hline Frustaci et al. (86) & $A \& P$ & $41 / 0$ & $21(51 \%)$ & $20(49 \%)$ & nd & nd & \multicolumn{2}{|l|}{$\begin{array}{l}\text { EF/RCT, virus negative pts } \\
\text { improved }\end{array}$} \\
\hline Escher et al. (87) & $A \& P$ & 114 & Majority & Minority & nd & nd & \multicolumn{2}{|l|}{$\begin{array}{l}\text { EF } 6 \text { mo/observational, no co } \\
\text { biopsy }\end{array}$} \\
\hline References & No pts/Co & Treatment & Endpoints & $\begin{array}{l}\text { Treated pts } \\
\text { improved }\end{array}$ & $\begin{array}{l}\text { Treated pts } \\
\text { Unch/deter. }\end{array}$ & $\begin{array}{l}\text { Controls } \\
\text { improved }\end{array}$ & Controls unch/deter. & Comments \\
\hline \multicolumn{9}{|c|}{ B. DOUBLE BLIND, RANDOMIZED, AND CONTROLLED TREATMENT TRIALS (RCT) WITH IMMUNOSUPPRESSIVE DRUGS IN MYOCARDITIS } \\
\hline Parillo et al. (88) & $51 / 51$ & P vs. Pl & $\begin{array}{l}\text { EF after } 3 \\
\text { mo, mortality }\end{array}$ & $\begin{array}{l}53 \% \\
\text { No difference }\end{array}$ & $\begin{array}{l}47 \% \\
\text { No difference }\end{array}$ & $\begin{array}{l}27 \% \\
\text { No difference }\end{array}$ & $\begin{array}{l}73 \% \\
\text { No difference }\end{array}$ & $\begin{array}{l}\text { RCT, } \\
\text { no PCR }\end{array}$ \\
\hline Mason et al. (89) MTT & $64 / 47$ & $\begin{array}{l}\text { A/C \& } P \\
\text { vs. PI }\end{array}$ & $\begin{array}{l}\text { EF/function } \\
\text { +Mortality }\end{array}$ & $\begin{array}{l}\text { No difference } \\
\text { No difference }\end{array}$ & $\begin{array}{l}\text { No difference } \\
\text { No difference }\end{array}$ & $\begin{array}{l}\text { No difference } \\
\text { No difference }\end{array}$ & $\begin{array}{l}\text { No difference } \\
\text { No difference }\end{array}$ & RCT, no PCR (90) \\
\hline Wojnicz et al. (91) & $41 / 43$ & $\begin{array}{l}\text { A \& P } \\
\text { vs. PI }\end{array}$ & EF/function & In majority & In minority & $\begin{array}{l}\text { Minority with } \\
\text { spontaneous } \\
\text { improvement }\end{array}$ & Majority & $\begin{array}{l}\text { No PCR, HLA as } \\
\text { criterium } \\
\text { of inflammation }\end{array}$ \\
\hline $\begin{array}{l}\text { Cooper et al. (74), Maisch } \\
\text { et al. }(69,70)\end{array}$ & $11 / ?$ & $\begin{array}{l}\text { Cyclo+P } \\
\text { vs. PI }\end{array}$ & $\begin{array}{l}\text { Mortality } \\
12 \mathrm{mo}\end{array}$ & Improved & nd & nd & nd & $\begin{array}{l}\text { RCT, stopped for } \\
\text { lack of pts }\end{array}$ \\
\hline $\begin{array}{l}\text { Frustaci et al. (92) } \\
\text { TIMIC }\end{array}$ & $43 / 42$ & $\begin{array}{l}\text { A \& P } \\
\text { vs. PI }\end{array}$ & $\begin{array}{l}\text { EF ( } 6 \text { mo) } \\
\text { Mortality }\end{array}$ & $\begin{array}{l}88,3 \\
\text { nd }\end{array}$ & $\begin{array}{l}11,7 \\
\text { nd }\end{array}$ & $\begin{array}{l}0 \\
\text { nd }\end{array}$ & $\begin{array}{l}100 \\
\text { nd }\end{array}$ & $\begin{array}{l}\text { WHF, RCT, virus } \\
\text { negative pts only }\end{array}$ \\
\hline $\begin{array}{l}\text { Maisch et al. (93) } \\
\text { ESETCID }\end{array}$ & $54 / 47$ & $\begin{array}{l}\text { Tx arms with } \\
\text { A\&P } \\
\text { vs. PI }\end{array}$ & $\begin{array}{l}\text { EF/function } \\
\text { MACE }\end{array}$ & $\begin{array}{l}\text { EF+MACE } \\
\text { improved } \\
\text { after } 6 \text { month }\end{array}$ & & $\begin{array}{l}\text { Some } \\
\text { spontaneous } \\
\text { improvement }\end{array}$ & & $\begin{array}{l}\text { WHF, RCT, } \\
\text { intermediate results }\end{array}$ \\
\hline
\end{tabular}

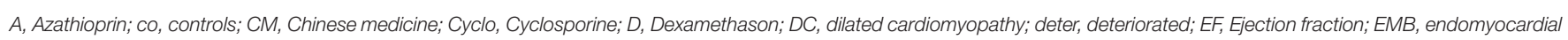

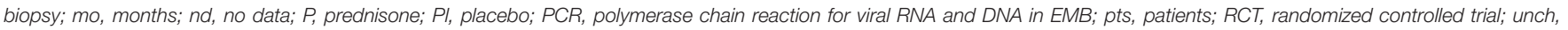
unchanged; WHF, quantitative World Heart Federation biopsy criteria.

f) As idiopathic form.

Classic Löffler's endocarditis develops in 3 stages:

1) Eosinophilic endomyocarditis, in which mature eosinophils infiltrate the endocardium and myocardium and damage with their products such as the cationic protein or by IL-5, which has also been discussed as a late mediator of fibrosis.

2) Thrombotic endocardial disease, in which apical obliteration and valve involvement occur.
3) Endomyocardial fibrosis as terminal stage, in which restrictive cardiomyopathy prevails.

The 3 stages can be identified noninvasively by colorflow Doppler echocardiography, cardiac MRI, and by EMB. In the peripheral blood the eosinophils can sometimes be degranulated. They are diagnosed as neutrophils, which obviously impairs the diagnosis of eosinophilia. The definite diagnosis should be established by endomyocardial biopsy. The causative therapy of the tropical form is the treatment of the underlying helminthic or protozoal infection. In all other 
forms immunosuppression has been recommended either by prednisone, interferon or the tyrosinekinase inhibitors imatinib or mepolizumab. As a humanized monoclonal antibody mepolizumab binds to and inhibits interleukin-5 (IL-5). In the Marburg registry longterm prednisone and azathioprine gave a survival rate of 9 out 10 patients over a mean period of 8.4 years (9).

\section{Rheumatic Diseases and Collagen Disorders With Cardiac Manifestations}

Cardiac symptoms may be "behind the curtain" of the clinical manifestations in rheumatic diseases. The diagnosis relies on clinical manifestation, echocardiography, cardiac MRI, and sometimes on endomyocardial biopsy and/or pericardiocentesis. The management includes pain relief with NSAIDs, immunosuppression as systemic therapy, and in patients with larger pericardial effusions undergoing pericardiocentesis with intrapericardial instillation of triamcinolone acetate. Longterm, oral colchicine (2-3 tablets per day with $0.5 \mathrm{mg}$ ) is recommended (9).

\section{Autoreactive Myocarditis}

It is common belief that an infection with cardiotropic viruses may cause sequestration of myocardial cells. This can trigger in predisposed patients an autoreactive cellular and humoral immune reaction which in turn leads to further myocardial damage.

With this hypothesis in mind immunosuppressive treatment either by prednisone alone or in combination with azathioprin or cyclosporin was initiated. However, most studies listed in Table 4A were carried out before quantitative immunohistochemistry for the assessment of the infiltrate and PCR for cardiotropic viruses were available. So it remained unclear, if prednisone and immunosuppression were started when virus particles were still present. According to a current dogma, in such a situation immunosuppression is contraindicated.

Our controlled pilot study on immunosuppression (80) before the initiation of ESETCID (93) excluded patients with a viral genome in the myocardium and was therefore directed to autoreactive, virus-negative myocarditis cases. It demonstrated improvement of cardiac function (EF $>5 \%$ after 6 months) in $47 \%$ of patients treated with verum, but also in $14 \%$ in the placebo group, which could be interpreted as spontaneous recovery.

In a post-hoc stratification of myocarditis patients treated with prednisone and azathioprine Frustaci et al. (86) also found that improvement with immunosuppression was demonstrable only in the virus-negative cases.

The first randomized controlled trial on prednisone in patients with idiopathic dilated cardiomyopathy with biopsies taken was carried out by Parillo et al (88), who randomly assigned 102 DCM patients to treatment with $60 \mathrm{mg} / \mathrm{d}$ for 3 months or without prednisone. $53 \%$ of the patients who received prednisone showed improvement of ejection fraction by $>5 \%$, but only $27 \%$ of the controls improved spontaneously $(p=0.005)$.

The Myocarditis Treatment Trial (MTT) by Mason et al. (89) showed neither benefit nor harm. Mortality after 6 months of treatment with cyclosporin A or azathioprine and prednisone showed an insignificant trend when compared to placebo. The study was underpowered and did not distinguish viral from non-viral disease as pointed out later (90). Wojnicz et al. (91) randomized 84 patients with dilated heart muscle disease and suspected myocarditis when an increased HLA MHC expression was found in EMB. Treatment of azathioprine and prednisone was compared with placebo after 3 months. In the treatment group ejection fraction improved, survival remained comparable, however, between verum and placebo groups.

In the TIMIC study the ejection fraction in the treatment group of 43 patients increased from $26.5 \%$ at baseline to $45.6 \%$ after 6 months $(p<0.001)$. Accordingly left ventricular enddiastolic volume, left ventricular enddiastolic diameter, and New York Heart Association class decreased significantly (92).

The ESETCID (European Study on the Epidemiology and Treatment of Cardiac Inflammatory Disease) is a double blind, randomized, placebo controlled three-armed trial with prednisolone and azathioprine for autoreactive (virus negative) inflammatory dilated cardiomyopathy in patients with an ejection fraction $<45 \%$ at baseline. Its intermediate results from the immunosuppressive treatment arm demonstrated a positive trend in EF and MACE after 6 months of treatment and a significant benefit after 1 year of follow-up (93). For the initial and steady state dosages of prednisolone and azthioprine see Maisch et al. (93). The control group without immunosuppressive treatment also showed some spontaneous resolution of the infiltrate.

\section{INTRAVENOUS IMMUNOGLOBULIN}

Intravenous immunoglobulins (ivIg) interact widely with the host immune system. They can stimulate anti-inflammatory cytokines, develop anti-idiotypic activities, increase FCgamma receptor saturation and the expression of the inhibitory FCgRIIB. Inhibitory actions comprise the suppression of proinflammatory cytokines, the interruption of the complement cascade, the inhibition of dendritic cells, of leukocyte adhesion, of apoptosis and of metalloproteinases. They can bind microbial particles, contribute to the self-antigen sequestration and interfere with $\mathrm{B}$ and $\mathrm{T}$ cell regulation (9). Anthony et al have shown that the anti-inflammatory activity of monomeric IgG depends on the sialysation of the N-linked glycan of the IgG Fc fragment (101). Their beneficial effect has also been reported in different clinical settings of autoimmune disease including acute and chronic myocarditis, in dilated cardiomyopathy, in experimental enteroviral myocarditis (102) and in Parvovirus B19 associated heart disease (103). IgM and IgA enriched immunoglobulins appear to be effective in lower doses (104).

Table 5 gives an overview on the ivIg studies. Many, but not all studies reported hemodynamic benefit or clinical improvement. The IMAC, a randomized controlled trial, demonstrated improvement in both, the treatment and placebo 
TABLE 5 | Iv-Immunoglobulin treatment in myocarditis and inflammatory dilated cardiomyopathy.

\begin{tabular}{|c|c|c|c|c|c|c|}
\hline References & Design & $n$ & EMB & Viral PCR & Ivlg dose & Outcome \\
\hline Drucker et al. (105) & $\begin{array}{l}\text { Retrospective, } \\
\text { historic control }\end{array}$ & 46 children & Partly & nd & $2 \mathrm{~g} / \mathrm{kg}$ single dose & Reduced LVEDD \\
\hline McNamara et al. (106) & Uncontrolled & 10 adults & Partly & nd & $2 \mathrm{~g} / \mathrm{kg}$ & $\begin{array}{l}\text { Improvement of EF } \\
\text { after } 12 \text { months }\end{array}$ \\
\hline Takeda et al. (107) & Case report & 1 & Myocarditis & EBV & $2 \mathrm{~g} / \mathrm{kg}$ for 2 days & Improvement \\
\hline Nigro et al. (108) & Case reports & 3 children & Myocarditis & Parvo B19 & $2 \mathrm{~g} / \mathrm{kg}$ over 5 days & Improved \\
\hline Tsai et al. (109) & Case report & 1 child & nd & $\begin{array}{l}\text { Mycoplasma } \\
\text { peumoniae } \\
\text { (serology) }\end{array}$ & $2 \mathrm{~g} / \mathrm{kg}$ over 2 days & Improved \\
\hline McNamara et al. (110) IMAC & $\mathrm{RCT}$ & 62 & $\begin{array}{l}\text { Only ten active and } \\
3 \text { borderline } \\
\text { myocarditis }\end{array}$ & nd & $\begin{array}{l}2 \mathrm{~g} / \mathrm{kg} \text {, single shot } \\
\text { vs. controls }\end{array}$ & Not improved \\
\hline Alter et al. (111) & Case report & 1 & Myocarditis & Varicella & 2 g/kg over 2 days & Normalized \\
\hline Shioji et al. (112) & Case report & 1 & $\begin{array}{l}\text { Fulminant } \\
\text { myocarditis }\end{array}$ & $\begin{array}{l}\text { nd, negative } \\
\text { serology }\end{array}$ & $2 \mathrm{~g} / \mathrm{kg}$ & Improved \\
\hline Tedeschi et al. (113) & Case report & 1 & nd & $\begin{array}{l}\text { nd, negative } \\
\text { serology }\end{array}$ & $2 \mathrm{~g} / \mathrm{kg}$ & Improved \\
\hline Kishimoto et al. (114) & Case series & 9 adults & 4 myocarditis only & nd & $1-2 \mathrm{~g} / \mathrm{kg}$ & $\begin{array}{l}\text { Improved NYHA, EF } \\
\& \text { SF }\end{array}$ \\
\hline Wang et al. (115) & Case report & 1 child & $\begin{array}{l}\text { Fulminant } \\
\text { myocarditis }\end{array}$ & Coxsackie A 16 & 1/kg for 2 days & Patient died \\
\hline Dennert et al. (116) & Uncontrolled & 25 & $\begin{array}{l}\text { post mortem } \\
\text { myocarditis }\end{array}$ & Parvo B19 & $2 \mathrm{~g} / \mathrm{kg}$ & $\begin{array}{l}\text { Decrease in viral } \\
\text { load and improved } \\
\text { EF after } 6 \text { months }\end{array}$ \\
\hline Maisch et al. (117) & Controlled & $\begin{array}{l}18 \text { (ivlg) vs. } \\
17 \text { (controls) }\end{array}$ & CMV myocarditis & CMV by PCR or ISH & $\begin{array}{l}14 \text { days, multiple } \\
\text { doses }\end{array}$ & $\begin{array}{l}\text { Improved and } \\
\text { eradicated CMV }\end{array}$ \\
\hline
\end{tabular}

Modified from Maisch and Pankuweit $(9,10)$ with permission from Springer-Nature.

CMV, Cytomegalovirus; DC, dilated cardiomyopathy; deter, deteriorated; EBV, Epstein Barr virus; EF, Ejection fraction; EMB, endomyocardial biopsy; ISH, in situ hybridization; LVEDD,

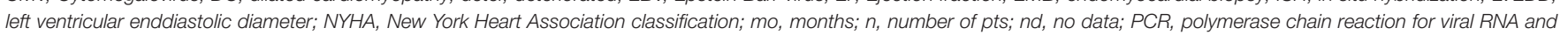
DNA in EMB; RCT, randomized controlled trial; SF, shortening fraction; unch, unchanged.

arms (110), so that in a multi-institutional analysis the benefit in a pediatric myocarditis or cardiomyopathy population was questioned (118).

In CMV-myocarditis one controlled trial of 18 patients showed the eradication of inflammation and the elimination of the virus (117). The patients had received $2 \mathrm{ml} / \mathrm{kg}$ i.v. cytomegalovirus hyperimmunoglobulin (CMVhIg) for 3 days and $1 \mathrm{ml} / \mathrm{kg}$ for 2 additional 2 days.

In a case of varicella myocarditis high-dose immunoglobulins demonstrated clinical improvement and the resolution of inflammation (111).

In the Marburg Registry 20 g i.v. pentaglobin (ivIgGAM) given in adenoviral myocarditis resulted in clinical improvement by the eradication of the inflammatory infiltrate and the virus. In Parvo B19 myocarditis clinical improvement and elimination of inflammation in the biopsy is noted, whereas the virus may still persist although the viral load may decrease.

\section{IMMUNOADSORPTION}

The therapeutical concept of immunoadsorption follows a different concept: the elimination of cardiotoxic autoantibodies together with proinflammatory cytokines. The positive result of a pilot study of patients with idiopathic dilated cardiomyopathy needs further confirmation in a larger endpoint study $(119,120)$.

\section{ANTIVIRAL TREATMENT Interferon-Beta}

Interferons belong to the natural defense system against many viral infections. In entero- and adenoviral myocarditis interferon-beta has eliminated the viral genome and decreased inflammation in a phase 2 study, when applying dosages of 2 to $6 \times 10^{6}$ IU every 2 nd day (121). The response to interferon-beta in Parvovirus B19 and human herpes virus 6 myocarditis has been less impressive as shown by the BICC study (122).

\section{PERSPECTIVE AND CONCLUSION}

Although we have learned much about inflammatory heart disease from various animal models of viral or autoimmune myocarditis, we are aware that animal models cannot be translated one to one to myocarditis in patients. Enteroviral myocarditis in man has almost completely disappeared in Europe. Parvovirus B 19 as infective agent has emerged instead but its pathogenesis is still poorly understood and animal models for this virus are still missing. Separation of myocarditis in 3 
phases is an auxiliary construction. But myocardial inflammation in man is continuum. Personalized treatment should be tailored within the time frame from infection to innate and adaptive response. There is still much work to be done.

\section{REFERENCES}

1. Kerr WW. Myocarditis. Cal State J Med. (1904) 2:369-71.

2. Maisch B, Trostel-Soeder R, Stechemesser E, Berg PA, Kochsiek K. Diagnostic relevance of humoral and cell-mediated immune reactions in patients with acute viral myocarditis. Clin Exp Immunol. (1982) 48:533-45.

3. Linde A, Mosier D, Blecha F, Melgarejo T. Innate immunity and inflammation - new frontiers in comparative cardiovascular pathology. Cardiovasc Res. (2007) 73:26-36. doi: 10.1016/j.cardiores.2006.08.009

4. Portig I, Pankuweit S, Maisch B. Antibodies against stress proteins in the sera of patients with dilated cardiomyopathy. J Mol Cell Cardiol. (1997) 29:2245-51. doi: 10.1006/jmcc.1997.0463

5. Wicks EC, Elliott PM. Genetics and metabolic cardiomyopathies. Herz. (2012) 37:598-611. doi: 10.1007/s00059-012-3659-0

6. Kloos W, Katus HA, Meder B. Genetic cardiomyopathies. Lessons learned from humans, mice, and zebrafish. Herz. (2012) 37:612-8. doi: 10.1007/s00059-012-3651-8

7. Elliott P, Andersson B, Arbustini E, Bilinska Z, Cecchi F, Charron P, et al. Classification of the cardiomyopathies: a position statement from the European Society of Cardiology working group on myocardial and pericardial disease. Eur Heart J. (2007) 29:270-6. doi: 10.1093/eurheartj/ehm342

8. Caforio A, Pankuweit S, Charron P, et al. Current state of knowledge on aetiology, diagnosis, management and therapy of myocarditis: a position statement of the European Society of Cardiology Working Group on Myocardial and Pericardial Diseases. Eur Heart J. (2013) 34:2636-48. doi: 10.1093/eurheartj/eht210

9. Maisch B, Pankuweit S. Current treatment options in (peri)myocarditis and inflammatory cardiomyopathy. Herz. (2012) 37:644-56. doi: 10.1007/s00059-012-3679-9

10. Maisch B, Alter P. Treatment options in myocarditis and inflammatory cardiomyopathy. Focus on i.v. immunoglobulins. Herz. (2018) 43:423-30. doi: 10.1007/s00059-018-4719-x

11. Hickie JB, Hall GV. The cardiomyopathies: a report of fifty cases. Australas Ann Med. (1960) 9:258-70. doi: 10.1111/imj.1960.9.4.258

12. Anonymous. Report of the WHO/ISFC Task Force on the definition and classification of cardiomyopathies. Br Heart J. (1980) 44:672-74. doi: 10.1136/hrt.44.6.672

13. Richardson P, McKenna W, Bristow M, Maisch B, Mautner B, O'Connell J, et al. Report of the 1995 World Health Organization/International Society and Federation of Cardiology Task Force on the definition and classification of cardiomyopathies. Circulation. (1996) 93:841-2. doi: 10.1161/01.CIR.93.5.841

14. Aretz HT. Myocarditis: the Dallas criteria. Hum Pathol. (1987) 18:619-24. doi: 10.1016/S0046-8177(87)80363-5

15. Maisch B, Bültmann B, Factor S, Groene HJ, Hufnagel G, Kawarmura K, et al. World Heart Federation consensus conferences's definition of inflammatory cardiomyopathy (myocarditis): report from two expert committees on histology and viral cardiomyopathy. Heartbeat. (1999) 4:3-4.

16. Maisch B, Portig I, Ristic A, Hufnagel G, Pankuweit S. Definition of inflammatory cardiomyopathy (myocarditis): on the way to consensus. Herz. (2000) 25:200-9. doi: 10.1007/s000590050007

17. Pankuweit S, Portig I, Eckhardt H, Crombach M, Hufnagel G, Maisch B. Prevalence of viral genome in endomyocardial biopsies from patients with inflammatory heart muscle disease. Herz. (2000) 25:221-6. doi: 10.1007/s000590050010

18. Swirski FK, Nahrendorf M. Cardioimmunology: the immune system in cardiac homeostasis and disease. Nat Rev Immunol. (2018) 18:733-44. doi: 10.1038/s41577-018-0065-8

\section{AUTHOR CONTRIBUTIONS}

The author confirms being the sole contributor of this work and has approved it for publication.

19. Hulsmans M, Clauss S, Xiao L, Aguirre AD, King KR, Hanley A, et al. Macrophages facilitate electrical conduction in the heart. Cell. (2017) 169:510-22. doi: 10.1016/j.cell.2017.03.050

20. Horckmans M, Bianchini M, Santovito D, Megens RTA, Springael JY, Negri I, et al. Pericardial adipose tissue regulates granulopoiesis, fibrosis, and cardiac function after myocardial infarction. Circulation. (2018) 137:948-60. doi: 10.1161/CIRCULATIONAHA.117.028833

21. Butts B, Lee A. Goeddel LA, George DJ, Steele C, Davies JE, et al. Increased inflammation in pericardial fluid persists 48 hours after cardiac surgery. Circulation. (2017) 136:2284-6. doi: 10.1161/CIRCULATIONAHA.117.029589

22. Lévêque N, Garcia M, Bouin A, Nguyen JHC, Tran GP, Andreoletti L, et al. Functional consequences of RNA $5=$-terminal deletions on coxsackievirus B3 RNA replication and ribonucleoprotein complex formation. J Virol. (2017) 91:e00423-17. doi: 10.1128/JVI.00423-17

23. Huber SA, Lodge PA. Coxsackievirus B-3 myocarditis in BALB/c mice: evidence for autoimmunity to myocyte antigens. J Pathol. (1984) 116:21-9.

24. Rose NR, Wolfgram LJ, Herskowitz A, Beisel KW. Postinfectious autoimmunity: two distinct phases of Coxsackievirus B3induced myocarditis. Ann N Y Acad Sci. (1986) 475:146-56. doi: 10.1111/j.1749-6632.1986.tb20864.x

25. Rose NR. Critical cytokine pathways to cardiac inflammation. J Interferon Cytok Res. (2011) 31:705-9. doi: 10.1089/jir.2011.0057

26. Huber S, Ramsingh AI. Coxsackievirus-induced pancreatitis. Viral Immunol. (2004) 17: 358-69. doi: 10.1089/vim.2004.17.358

27. Latz E, Xiao TS, Stutz A. Activation and regulation of the inflammasomes. Nat Rev Immunol. (2013) 13:397-411. doi: 10.1038/nri3452

28. Maisch B, Deeg P, Liebau G, Kochsiek K. Diagnostic relevance of humoral and cytotoxic immune reactions in primary and secondary dilated cardiomyopathy. Am J Cardiol. (1983) 52:1072-8. doi: 10.1016/0002-9149(83)90535-0

29. Maisch B, Bauer E, Cirsi M, Kochsiek K. Cytolytic cross-reactive antibodies directed against the cardiac membrane and viral proteins in coxsackievirus B3 and B4 myocarditis. Characterization and pathogenetic relevance. Circulation. (1993) 87:49-65.

30. Maisch B. The sarcolemma as antigen in the secondary immunopathogenesis of myopericarditis. Eur Heart J. (1987) 8(Suppl J):155-65. doi: 10.1093/eurheartj/8.suppl_J.155

31. Pankuweit S, Portig I, Lottspeich F, Maisch B. Autoantibodies in sera of patients with myocarditis: characterization of the corresponding proteins by isoelectric focusing and N-terminal sequence analysis. J Mol Cell Cardiol. (1997) 29:77-84. doi: 10.1006/jmcc.1996.0253

32. Maisch B, Wedeking U, Kochsiek K. Quantitative assessment of antilaminin antibodies in myocarditis and perimyocarditis. Eur Heart J. (1987) 8(Suppl J):223-35. doi: 10.1093/eurheartj/8.suppl_J.233

33. Obermayer U, Scheidler J, Maisch B. Antibodies against micro- and intermediate filaments in carditis and dilated cardiomyopathy - are they a diagnostic marker? Eur Heart J. (1987) 8(Suppl. J):181-6. doi: 10.1093/eurheartj/8.suppl_J.181

34. Klein R, Maisch B, Kochsiek K, Berg PA. Demonstration of organ specific antibodies against heart mitochondria (anti M7) in sera from patients with some forms of heart diseases. J Clin Exp Immunol. (1984) 58:283-92.

35. Pohlner K, Portig I, Pankuweit S, Lottspeich F, Maisch B. Identification of mitochondrial antigens recognized by the antibodies in sera of patients with dilated cardiomyopathy by two-dimensional gel electrophoresis and protein sequencing. Am J Cardiol. (1997) 80:1040-5. doi: 10.1016/S0002-9149(97)00600-0 
36. Caforio AL, Tona F, Bottaro S, Vinci A, Dequal G, Daliento L, et al. Clinical implications of anti-heart autoantibodies in myocarditis and dilated cardiomyopathy. Autoimmunity. (2008) 41:35-45. doi: 10.1080/08916930701619235

37. Kaya Z, Leib C, Katus HA. Autoantibodies in heart failure and cardiac dysfunction. Circ Res. (2012) 110:145-58. doi: 10.1161/CIRCRESAHA.111.243360

38. Wallukat G, Wollenberg A, Morwinski R, Pitschner HF. Anti-beta1adrenoceptor autoantibodies with chronotropic activity from the serum of patients with dilated cardiomyopathy: mapping of epitopes in the first and second extracellular loops. J Mol Cell Cardiol. (1995) 27:3977-4006. doi: 10.1016/S0022-2828(08)80036-3

39. Jahns R, Boivin V, Siegmund C, Inselmann G, Lohse MJ, Boege F, et al. Autoantibodies activating human beta 1-adrenergic receptors are associated with reduced cardiac function in chronic heart failure. Circulation. (1999) 99:649-54. doi: 10.1161/01.CIR.99.5.649

40. Fu LX, Magnusson Y, Bergh CH, Liljeqvist JA, Waagstein F, Hjalmarson A, et al. Localization of a functional autoimmune epitope on the second extracellular loop of the human muscarinic acetylcholin receptor 2 in patients with idiopathic dilated cardiomyopathy. J Clin Invest. (1993) 91:1964-8. doi: 10.1172/JCI116416

41. Maisch B, Lotze U, Schneider J, Kochsiek K. Antibodies to human sinus node in sick-sinus syndrome. Pacing Clin Electrophysiol. (1986) 9:1101-9. doi: 10.1111/j.1540-8159.1986.tb06677.x

42. Lotze U, Maisch B. Humoral immune response to cardiac conducting tissue. Springer Semin Immunopathol. (1989) 11:409-22. doi: 10.1007/BF00201879

43. Maisch B. Autoreactivity to the cardiac myocyte, connective tissue and the extracellular matrix in heart disease and postcardiac injury. Springer Semin Immunopathol. (1989) 11:369-95. doi: 10.1007/BF00201877

44. Goin JC, Borda ES, Auger S, Storino R, Sterin-Borda L. Cardiac M(2) muscarinic cholinoceptor activation by human chagasic autoantibodies: association with bradycardia. Heart. (1999) 82:273-8. doi: $10.1136 /$ hrt.82.3.273

45. Schultheiss HP, Bolte HD. Immunological analysis of autoantibodies against the adenine nucleotide translocator in dilated cardiomyopathy. J Mol Cell Cardiol. (1988) 17:603-17. doi: 10.1016/S0022-2828(85)8 0029-8

46. Limas CJ, Limas C, Kubo SH, Olivari MT. Anti- $\beta$-receptor antibodies in human dilated cardiomyopathy and correlation with HLA-DR antigens. Am J Cardiol. (1990) 65:483-7. doi: 10.1016/0002-9149(90)90815-I

47. Jahns R, Bolvin V, Hein L, Triebel S, Angermann CE, Ertl G, et al. Direct evidence for a $ß 1$-adrenergic receptor-directed autoimmune attack as a cause of idiopathic dilated cardiomyopathy. J Clin Invest. (2004) 113:1419-29. doi: 10.1172/JCI200420149

48. Naparstek Y, Plotz PH. The role of autoantibodies in autoimmune disease. Ann Rev Immunol. (1993) 11:79-104. doi: 10.1146/annurev.iy.11.040193.000455

49. Wolff PG, Kühl U, Schultheiss HP. Laminin distribution and autoantibodies to laminin in dilated cardiomyopathy and myocarditis. Am Heart J. (1989) 117:1303-9.

50. Ansari AA, Wang YC, Danner DJ, Gravanis MB, Mayne A, Neckelmann N, et al. Abnormal expression of histocompatibility and mitochondrial antigens by cardiac tissue from patients with myocarditis and dilated cardiomyopathy. Am J Pathol. (1991) 139:337-54.

51. Wittner B, Maisch B, Kochsiek K. Quantification of antimyosin antibodies in experimental myocarditis by a new solid-phase fluorometric assay. $J$ Immunol Methods. (1983) 64:239-47. doi: 10.1016/0022-1759(83)90402-7

52. Caforio AL, Goldman JH, Haven AJ, Baig KM, McKenna WJ. Evidence for autoimmunity to myosin and other heart-specific autoantigens in patients with dilated cardiomyopathy and their relatives. Int J Cardiol. (1996) 54:15763. doi: 10.1016/0167-5273(96)02593-4

53. Göser S, Andrassy M, Buss S, Leuschner F, Volz CH, Ottl R, et al. Cardiac troponin I but not cardiac troponin $\mathrm{T}$ induces severe autoimmune inflammation in the myocardium. Circulation. (2006) 114:1693-702. doi: 10.1161/CIRCULATIONAHA.106.635664

54. Herzum M, Maisch B, Kochsiek K. Circulating immune complexes in perimyocarditis and infective endocarditis. Eur Heart J. (1987) 8(Suppl. J):323-6. doi: 10.1093/eurheartj/8.suppl_J.323
55. Leone O, Veinot JP, Angelini A, Baandrup UT, Basso C, Berry G, et al. 2011 Consensus statement on endomyocardial biopsy from the Association for European Cardiovascular Pathology and the Society for Cardiovascular Pathology. Cardiovasc Pathol. (2012) 21:245-74. doi: 10.1016/j.carpath.2011.10.001

56. Kindermann I, Barth C, Mahfoud F, Ukena C, Lenski M, Yilmaz A, et al. Update on myocarditis. J Am Coll Cardiol. (2012) 59:779-92. doi: 10.1016/j.jacc.2011.09.074

57. Sagar S, Liu PP, Cooper LT. Myocarditis. Lancet. (2012) 379:738-47. doi: 10.1016/S0140-6736(11)60648-X

58. Maisch B, Richter A, Sandmöller A, Portig I, Pankuweit S, BMBF-Heart Failure Network. Inflammatory dilated cardiomyopathy (DCMI). Herz. (2005) 30:535-44. doi: 10.1007/s00059-005-2730-5

59. Dennert R, Crijns HJ, Heymans S. Acute viral myocarditis. Eur Heart J. (2008) 29:2073-82. doi: 10.1093/eurheartj/ehn296

60. Pankuweit S, Moll R, Baandrup U, Portig I, Hufnagel G, Maisch B. Prevalence of the parvovirus B19 genome in endomyocardial biopsy specimens. Hum Pathol. (2003) 34:497-503. doi: 10.1016/S0046-8177(03)00078-9

61. Bock CT, Klingel K, Kandolf R. Human parvovirus B19-associated myocarditis. N Engl J Med. (2010) 362:1248-9. doi: 10.1056/NEJMc0911362

62. Maisch B. Effusive-constrictive pericarditis: current perspectives. J Cardiovasc Diagn Interv. (2018) 6:7-14. doi: 10.2147/JVD.S1 25950

63. Boucher D, Monteleone M, Coll RC, Chen KW, Ross CM, Teo $\mathrm{JL}$, et al. Caspase-1 self-cleavage is an intrinsic mechanism to terminate inflammasome activity. J Exp Med. (2018) 215:827-40. doi: 10.1084/jem.20172222

64. De Rosa S, Eposito F, Carella C, Strangio A, Ammirati G, Sabatino J, et al. Transcoronary concentration gradients of circulating microRNAs in heart failure. Eur J Heart Fail. (2018) 20:1000-10. doi: 10.1002/ejh f.1119

65. Waagstein F, Hjalmarson A, Varnauskas E, Walentin L. Effect of betaadrenergic receptor blockade in congestive cardiomyoapthy. Br Heart J. (1975) 37:1022-36. doi: 10.1136/hrt.37.10.1022

66. Maisch B, Seferović PM, Ristić AD, Erbel R, Rienmüller R, Adler Y, et al. Guidelines on the diagnosis and management of pericardial diseases, executive summary; The Task force on the diagnosis and management of pericardial diseases of the European society of cardiology. Eur Heart J. (2004) 25:587-610. doi: 10.1016/j.ehj.2004.02.002

67. Adler Y, Charron P, Imazio M, Badano L, Barón-Esquivias G, Bogaert J, et al. 2015 ESC guidelines for the diagnosis and management of pericardial diseases. Eur Heart J. (2015) 36:2921-61. doi: 10.1093/ eurheartj/ehv318

68. Costanzo-Nordin MR, Reap EA, O'Connell JB, Robinson JA, Scanlon PJ. A nonsteroid anti-inflammatory drug exacerbates Coxsackie B3 murine myocarditis. J Am Coll Cardiol. (1985) 6:1078-82. doi: 10.1016/S0735-1097(85)80312-0

69. Maisch B. Management von Perikarditis und Perikarderguss, konstriktiver und effusiv-konstriktiver Perikarditis. Herz. (2018) 43:663-78.

70. Maisch B, Hufnagel G, Schönian U, Hengstenberg C. The European Study of Epidemiology and Treatment of Cardiac Inflammatory Disease (ESETCID). Eur Heart J. (1995) 16:173-5.

71. Kodama M, Matsumoto Y, Fujiwara M, Masani F, Izumi T, Shibata A. A novel experimental model of giant cell myocarditis induced in rats by immunization with cardiac myosin fraction. Clin Immunol Immunopathol. (1990) 57:250-62. doi: 10.1016/0090-1229(90)9 0039-S

72. Cooper LT, Berry GHJ, Shabetai R. Giant cell myocarditis: distinctions from lymphocytic myocarditis and cardiac sarcoidosis. J Heart Fail. (1997) 4:227230.

73. Cooper LT, Okura Y. Idiopathic giant cell myocarditis. Current treatment options. Cardiovasc Med. (2001) 3:463-7. doi: 10.1007/s11936-001-0020-y

74. Cooper LT, Berry GJ, Shabetai R. Idiopathic giant cell myocarditis - natural history and treatment. N Engl J Med. (1997) 336:1860-6. doi: 10.1056/NEJM199706263362603

75. Fenoglio JJ, Ursell PC, Kellogg CF, Drusin RE, Weiss MB. Diagnosis and classification of myocarditis by endomyocardial biopsy. N Engl J Med. (1983) 308:12-18. doi: 10.1056/NEJM198301063080103 
76. Hosenpud JD, McAnulty JH, Niles NR. Lack of objective improvement in ventricular systolic function in patients with myocarditis treated with azathioprine and prednisone. J Am Coll Cardiol. (1985) 6:797-801. doi: 10.1016/S0735-1097(85)80485-X

77. Anderson JL, Fowles RE, Unverferth DV, Mason JW. Immunosuppressive therapy of myocardial inflammatory disease. Initial experience and future trials to define indications for therapy. Eur Heart J. (1987) 8(Suppl J):263-6.

78. Marboe CC, Fenoglio JJ. Pathology and natural history of human myocarditis. Pathol Immunopathol Res. (1988) 7:226-39.

79. Latham RD, Mulrow JP, Virmani R, Robinowitz M, Moody JM. Recently diagnosed idiopathic dilated cardiomyopathy: incidence of myocarditis and efficacy of prednisone therapy. Am Heart J. (1989) 117:876-82. doi: 10.1016/0002-8703(89)90626-1

80. Maisch B, Schoenian U, Hengstenberg C, Herzum M, Hufnagel G, Bethge C, et al. Immunosuppressive therapy in autoreactive myocarditis: results from a controlled trial. Postgrad Med J. (1994) 70(Suppl. 1):S29-34.

81. Jühl U, Strauer BE, Schultheiss HP. Methylprednisolone in chronic myocarditis. Postgrad Med J. (1994) 70(Suppl. 1):S35-42.

82. Camargo PR, Snitcowsky R, da Luz PL, Mazzieri R, Higuchi ML, Rati M, et al. Favorable effects of immunosuppressive therapy in children with dilated cardiomyopathy and active myocarditis. Pediatr Cardiol. (1995) 16:61-8. doi: 10.1007/BF00796819

83. Liu D, Lei Y, Haixia J. Clinical search of Sheng Mai injection combined with corticosteroids for acute viral myocarditis in children. J Sichuan Tradit Chin Med. (2003) 21:59-60.

84. Sun D. Corticosteroid treatment effects in 36 cases diagnose with viral myocarditis with ventricle premature beats. J Zhenjiang Med Coll. (1999) 9:211-14.

85. Wu Y-Z, Chen B-W. Observation on curative effects of astragalus injection combined with glucocorticoids on acutely severe viral myocarditis. Zhongguo Zhong Xe Yi Jie He Ji Jui Za Zhi. (1999) 6:350-2.

86. Frustaci A, Chimenti C, Calabrese F, Pieroni M, Thiene G, Maseri A. Immunosuppressive therapy for active lymphocytic myocarditis: virological and immunologic profile for responders versus nonresponders. Circulation. (2003) 107:857-63. doi: 10.1161/01.CIR.0000048147.15962.31

87. Escher F, Kühl U, Lassner D, Poller W, Westermann D, Pieske B, et al. Long-term outcome of patients with virus negative chronic myocarditis or inflammatory cadiomyopathy after immunosuppressive therapy. Clin Res Cardiol. (2016) 105:1011-20. doi: 10.1007/s00392-016-1011-Z

88. Parillo JE, Cunnion RE, Epstein SE, Parker MM, Suffredini AF, Brenner $\mathrm{M}$, et al. A prospective, randomized, controlled trial of prednisone for dilated cardiomyopathy. $N$ Engl J Med. (1989) 321:1061-8. doi: 10.1056/NEJM198910193211601

89. Mason JW, O'Connel JB, Hershkowitz A, Rose NR, McManus BM, Billingham ME, et al. A clinical trial of immunosuppressive therapy for myocarditis. The myocarditis treatment trial investigators. $N$ Engl J Med. (1995) 33:269-75.

90. Maisch B, Camerini F, Schultheiss H-P. Immunosuppressive therapy for myocarditis (letter). N Engl J Med. (1995) 333:1713.

91. Wojnicz R, Nowalany-Kozielska E, Wojciechowska C, Glanowska G, Wilczewski P, Niklewski T, et al. Randomized, placebo-controlled study for immunosuppressive treatment of inflammatory dilated cardiomyopathy. Two-year follow-up results. Circulation. (2001) 104:39-45.

92. Frustaci A, Russo MA, Chimenti C. Randomized study on the efficacy of immunosuppressive therapy in patients with virus-negative inflammatory cardiomyopathy: the TIMIC study. Eur Heart J. (2009) 30:1995-2002. doi: 10.1093/eurheartj/ehp249

93. Maisch B, Kölsch S, Hufnagel G, et al. for the ESETCID Investigators. Orlando 2011, AHA Congress. Circulation. (2011) Suppl (Abstract).

94. Hufnagel G, Maisch B, Pfeiffer U. Immunhistologic investigations in suspected cardiac sarcoidosis. Eur Heart J. (1987) 8(Suppl. J):59-62. doi: 10.1093/eurheartj/8.suppl_J.59

95. Schoppet M, Pankuweit S, Moll R, Baandrup U, Maisch B. Images in cardiovascular medicine. Phenotype of infiltrating $\mathrm{T}$ lymphocytes in cardiac sarcoidosis. Circulation. (2002) 105:e67-8.

96. Valentonye R, Hampe J, Huse K, Rosenstiel P, Albrecht M, Stenzel A, et al. Sarcoidosis is associated with a truncating splice mutant in BTNL2. Nat Genet. (2005) 37:357-64. doi: 10.1038/ng1519
97. Meyer T, Lauschke J, Ruppert V, Richter A, Pankuweit S, Maisch B. Isolated cardiac sarcoidosis associated with the expression of a splice variant coding for a truncated BTNL2 protein. Cardiology. (2008) 109:117121. doi: 10.1159/000105552

98. Bargout R, Kelly RF. Sarcoid heart disease. Clinical course and treatment. Int J Cardiol. (2004) 97:173-82. doi: 10.1016/j.ijcard.2003.07.024

99. Spry CJ, Tai PC, Davies J. The cardiotoxicity of eosinophils. Postgrad Med J. (1983) 59:147-55. doi: 10.1136/pgmj.59.689.147

100. Tai PC, Ackerman SJ, Spry CJ, Dunnette S, Olsen EG, Gleich GJ. Deposits of eosinophil granule proteins in cardiac tissues of patients with eosinophilic endomyocardial disease. Lancet. (1987) 21:643-47. doi: 10.1016/S0140-6736(87)90412-0

101. Anthony RM, Nimmerjahn F, Ashline DJ, Reinhold VN, Paulson JC, Ravetch JV, et al. Recapitulation of IVIG anti-inflammatory activity with a recombinant Ig Fc. Science. (2008) 320:373-376. doi: $10.1126 /$ science. 1154315

102. Takada H, Kishimoto C, Hiraoka Y. Therapy with immunoglobulin suppresses myocarditis in a murine coxsackievirus B3 modelantiviral and anti-inflammatory effects. Circulation. (1995) 92:1604-11. doi: 10.1161/01.CIR.92.6.1604

103. Selbing A, Josefsson A, Dahle LO, Lindgren R. Parvovirus B19 infection during pregnancy treated with high-dose intravenous gammaglobulin. Lancet. (1995) 345:660-1. doi: 10.1016/S0140-6736(95)90569-3

104. Walpen AJ, Laumonier T, Aebi C, Mohacsi PJ, Rieben R. IgM enriched intravenous immunoglobulin inhibits classical pathway complement activation, but not bacterial killing by human serum. Xenotransplantation. (2004) 11:141-8. doi: 10.1046/j.1399-3089.2003.00098.x

105. Drucker NA, Colan SD, Lewis AB, Beiser AS, Wessel DL, Takahashi M, et al. Gamma-globulin treatment of acute myocarditis in the pediatric population. Circulation. (1994) 89:252-7. doi: 10.1161/01.CIR.89.1.252

106. McNamara DM, Rosenblum WD, Janosko KM, Trost MK, Villaneuva FS, Demetris AJ, et al. Intravenous immune gobulin in the therapy of myocarditis and acute cardiomyopathy. Circulation. (1997) 95:2476-8.

107. Takeda Y, Yasuda S, Miyazaki S, Daikoku S, Nakatani S, Nonogi H. Highdose immunoglobulin G therapy for fulminant myocarditis. Jap Circ J. (1998) 62:871-2. doi: $10.1253 /$ jcj.62.871

108. Nigro G, Bastianon V, Colloridi V, Ventriglia F, Gallo P, D’Amati G, et al. Human parvovirus B19 infection in infancy associated with acute and chronic lymphocytic myocarditis and high cytokine levels: report of 3 cases and review. Clin Infect Dis. (2000) 31:65-9. doi: 10.1086/313929

109. Tsai YG, Ou TY, Wang CC, Tsai MC, Yuh YS, Hwang B. Intravenous gammaglobulin therapy in myocarditis complicated with complete heart block: report of one case. Chung-Hua Min Kuo Hsiao Erh Ko I Hsueh Hui Ts Chih. (2001) 42:311-3.

110. McNamara DM, Holubkov R, Starling RC, Dec GW, Loh E, TorreAmione $\mathrm{G}$, et al. Controlled trial of intravenous immune globuline in recent-onset dilated cardiomyopathy. Circulation. (2001) 103:2254-549. doi: 10.1161/01.CIR.103.18.2254

111. Alter P, Grimm W, Maisch B. Varicella myocarditis in an adult. Heart. (2001) 85:E2. doi: 10.1136/heart.85.1.e2

112. Shioji K, Kishimoto C, Sasyama S. Immunoglobulin therapy for acute myocarditis. Resp Circul. (2000) 48:1133-9. doi: 10.1161/01.CIR.95. 11.2476

113. Tedeschi A, Airaghi L, Giannini S, Ciceri L, Massari FM. High-dose intravenous immunoglobulin in the treatment of acute myocarditis. A case report and review of the literature. J Intern Med. (2002) 251:169-73.

114. Kishimoto C, Fujita M, Kinoshita M, Iwase T, Tamaki S, Fujii M, et al. Immunglobulin therapy for myocarditis an acute dilated cardiomyopathy. Circulation. (2001) 103:220-5.

115. Wang CY, Li Lu F, Wu MH, Lee CY, Huang LM. Fatal coxsackievirus A16 infection. Pediatr Infect Dis J. (2004) 23:275-6. doi: 10.1097/01.inf.0000115950.63906.78

116. Dennert R, Velthuis S, Schalla S, Eurlings L, van Suylen RJ, van Paassen $\mathrm{P}$, et al. Intravenous immunoglobulin therapy for patients with idiopathic cardiomyopathy and endomyocardial biopsy-proven high PVB19 viral load. Antiviral Ther. (2010) 15:193-201. doi: 10.3851/IMP1516

117. Maisch B, Pankuweit S, Funck R, Koelsch S. Effective CMV hyperimmunoglobulin treatment in CMV myocarditis - A 
controled treatment trial. Eur Heart J. (2004) 25(Suppl.):114. doi: 10.1016/S0735-1097(16)31348-1

118. Klugman D, Berger JT, Sable CA, He J, Khandelwal SG, Slonim AD. Pediatric patients hospitalized with myocarditis: a multi-institutional analysis. Pediatr Cardiol. (2009) 31:222-8. doi: 10.1007/s00246-0099589-9

119. Müller J, Wallukat G, Dandel M, Bieda H, Brandes K, Spiegelsberger $\mathrm{S}$, et al. Immunoglobulin adsorption in patients with idiopathic dilated cardiomyopathy. Circulation. (2000) 101:385-91.

120. Wallukat G, Müller J, Hetzer R. Specific removal of betal-adrenergic autoantibodies from patients with idiopathic dilated cardiomyopathy. $N$ Engl J Med. (2002) 347:1806. doi: 10.1056/NEJM2002112834 72220

121. Kühl U, Pauschinger M, Schwimmbeck PL, Seeberg B, Lober C, Noutsias M, et al. Interferon-beta treatment eliminates cardiotropic viruses and improves left ventriclar function in patients with myocardial persistence of viral genomes and left ventricular dysfunction. Circulation. (2003) 107:2793-8. doi: 10.1161/01.CIR.0000072766.67150.51

122. Schultheiss HP, Piper C, Sowade O, Waagstein F, Kapp JF, Wegscheider $\mathrm{K}$, et al. Betaferon in chronic viral cardiomyopathy (BICC) trial: effects of interferon- $\beta$ treatment in patients with chronic viral cardiomyopathy. Clin Res Cardiol. (2016) 105:763-3. doi: 10.1007/s00392-016-0986-9

Conflict of Interest Statement: BM has received honoraria for lectures from Biotest Co.

Copyright (O) 2019 Maisch. This is an open-access article distributed under the terms of the Creative Commons Attribution License (CC BY). The use, distribution or reproduction in other forums is permitted, provided the original author(s) and the copyright owner(s) are credited and that the original publication in this journal is cited, in accordance with accepted academic practice. No use, distribution or reproduction is permitted which does not comply with these terms. 